\title{
Accounting for the vertical distribution of emissions in atmospheric $\mathrm{CO}_{2}$ simulations
}

\author{
Dominik Brunner ${ }^{1}$, Gerrit Kuhlmann ${ }^{1}$, Julia Marshall ${ }^{2}$, Valentin Clément ${ }^{3,4}$, Oliver Fuhrer $^{4}$, Grégoire Broquet ${ }^{5}$, \\ Armin Löscher ${ }^{6}$, and Yasjka Meijer ${ }^{6}$ \\ ${ }^{1}$ Empa, Swiss Federal Laboratories for Materials Science and Technology, Überlandstrasse 129, Dübendorf, Switzerland \\ ${ }^{2}$ Max Planck Institute for Biogeochemistry (MPI-BGC), Jena, Germany \\ ${ }^{3}$ Center for Climate Systems Modelling (C2SM), ETH Zürich, Zürich, Switzerland \\ ${ }^{4}$ Federal Institute of Meteorology and Climatology, MeteoSwiss, Kloten, Switzerland \\ ${ }^{5}$ Laboratoire des Sciences du Climat et de l'Environnement, CEA-CNRS-UVSQ, Université Paris Saclay, \\ 91191, Gif-sur-Yvette CEDEX, France \\ ${ }^{6}$ European Space Agency (ESA), ESTEC, Noordwijk, the Netherlands
}

Correspondence: Dominik Brunner (dominik.brunner@empa.ch)

Received: 10 September 2018 - Discussion started: 4 December 2018

Revised: 1 March 2019 - Accepted: 18 March 2019 - Published: 5 April 2019

\begin{abstract}
Inverse modeling of anthropogenic and biospheric $\mathrm{CO}_{2}$ fluxes from ground-based and satellite observations critically depends on the accuracy of atmospheric transport simulations. Previous studies emphasized the impact of errors in simulated winds and vertical mixing in the planetary boundary layer, whereas the potential importance of releasing emissions not only at the surface but distributing them in the vertical was largely neglected. Accounting for elevated emissions may be critical, since more than $50 \%$ of $\mathrm{CO}_{2}$ in Europe is emitted by large point sources such as power plants and industrial facilities. In this study, we conduct high-resolution atmospheric simulations of $\mathrm{CO}_{2}$ with the mesoscale Consortium for Small-scale Modeling model extended with a module for the simulation of greenhouse gases (COSMO-GHG) over a domain covering the city of Berlin and several coalfired power plants in eastern Germany, Poland and Czech Republic. By including separate tracers for anthropogenic $\mathrm{CO}_{2}$ emitted only at the surface or according to realistic, sourcedependent profiles, we find that releasing $\mathrm{CO}_{2}$ only at the surface overestimates near-surface $\mathrm{CO}_{2}$ concentrations in the afternoon on average by $14 \%$ in summer and $43 \%$ in winter over the selected model domain. Differences in columnaveraged dry air mole $\mathrm{XCO}_{2}$ fractions are smaller, between $5 \%$ in winter and $8 \%$ in summer, suggesting smaller yet nonnegligible sensitivities for inversion modeling studies assimilating satellite rather than surface observations. The results
\end{abstract}

suggest that the traditional approach of emitting $\mathrm{CO}_{2}$ only at the surface is problematic and that a proper allocation of emissions in the vertical deserves as much attention as an accurate simulation of atmospheric transport.

\section{Introduction}

Reliably predicting future atmospheric concentrations of $\mathrm{CO}_{2}$, the most important long-lived greenhouse gas, requires a profound understanding of the global carbon cycle, the contributions from anthropogenic and natural fluxes and their sensitivity to climate change, and political and societal drivers. An important tool for advancing our knowledge of the carbon cycle is the integration of $\mathrm{CO}_{2}$ observations with atmospheric transport simulations in an inverse modeling framework. Global inverse modeling systems helped to better constrain the terrestrial carbon budget, to allocate the global land sink to different continents and ecosystems, and to assess interannual variability and the sensitivity to climate variations (e.g., Bousquet et al., 2000; Chevallier et al., 2010; Peylin et al., 2013; van der Laan-Luijkx et al., 2017; Rödenbeck et al., 2018). Mesoscale inverse modeling systems assimilating observations from dense, regional in situ networks are increasingly being used to study biospheric fluxes at the 
regional scale (e.g., Sarrat et al., 2009; Goeckede et al., 2010; Broquet et al., 2011; Meesters et al., 2012).

The Paris Climate Agreement, adopted in 2015 (United Nations Framework Convention on Climate Change, 2016), which requires each signing partner nation to accurately report its greenhouse gas (GHG) emissions and to reduce emissions in the future following its Nationally Determined Contribution, has boosted the interest of the atmospheric science community in quantifying not only natural fluxes but also anthropogenic emissions of $\mathrm{CO}_{2}$. "Top-down" inverse estimation of anthropogenic emissions from atmospheric observations has in fact been proposed as an independent method to complement the traditional "bottom-up" collection of national emission inventories (Nisbet and Weiss, 2010). Several initiatives at the national and international level, such as the World Meteorological Organization (WMO)'s Integrated Global Greenhouse Gas Information System (IG3IS), have been launched to advance and harmonize inverse methods with the long-term vision to establish these methods as a policy-relevant verification and support tool. A summary of the state of the science in inverse modeling for verification of greenhouse gas inventories has recently been presented by Bergamaschi et al. (2018a).

Because of the great challenge of accurately estimating $\mathrm{CO}_{2}$ fluxes and distinguishing between the biospheric and anthropogenic contributions, the scientific community is calling for a globally integrated carbon observation and analysis system. This system should build on a substantially expanded ground-based and satellite observation capacity and should integrate observations and bottom-up data with atmospheric transport modeling in an inverse framework (Ciais et al., 2014). The individual components and necessary steps towards an operational European system for quantifying anthropogenic $\mathrm{CO}_{2}$ emissions were outlined in two recent reports to the European Commission (Ciais et al., 2015; Pinty et al., 2017).

A central component of this system is a constellation of $\mathrm{CO}_{2}$ satellites with imaging capability similar to the CarbonSat concept proposed by Bovensmann et al. (2010). The satellites are currently planned to be implemented in the framework of the European Earth observation Copernicus program and are commonly referred to as Sentinel- $\mathrm{CO}_{2}$. These satellites should be able to quantify the $\mathrm{CO}_{2}$ emissions from large sources such as power plants and cities during single overpasses. Corresponding observing system simulation experiments (OSSEs) were presented by Pillai et al. (2016) and Broquet et al. (2018).

In order to establish the requirements for the constellation of Sentinel- $\mathrm{CO}_{2}$ satellites, the European Space Agency (ESA) has launched several scientific support studies including the use of satellite measurements of auxiliary reactive trace gases for fossil fuel carbon dioxide emission estimation (SMARTCARB), a project that focused on the potential of complementary satellite measurements of $\mathrm{NO}_{2}$ or $\mathrm{CO}$ to improve the quantification of $\mathrm{CO}_{2}$ emissions from cities and power plants. The present study makes use of the highresolution atmospheric transport simulations conducted in SMARTCARB to address a specific topic beyond the main focus of the project. The core results of the SMARTCARB study will be presented elsewhere.

Estimating $\mathrm{CO}_{2}$ fluxes by inverse modeling requires accurate simulation of observed atmospheric $\mathrm{CO}_{2}$ concentrations. Systematic model biases are particularly critical as they tend to directly translate into biased flux estimates. Several studies investigated the impact of uncertainties in atmospheric transport on simulated $\mathrm{CO}_{2}$ concentrations and how they could be accounted for in an inverse modeling framework (e.g., Lin and Gerbig, 2005; Chan et al., 2008; Lauvaux et al., 2009). A particular focus was placed on potential biases introduced by errors in vertical transport in the planetary boundary layer (PBL) (Gerbig et al., 2008; Kretschmer et al., 2012, 2014). Uncertainties associated with bottom-up $\mathrm{CO}_{2}$ emissions were related to uncertainties in the horizontal gridding (Hogue et al., 2016) or the representation of the temporal variability (Liu et al., 2017).

Uncertainties associated with the vertical placement of emissions, conversely, have been largely ignored so far. In fact, in the vast majority of $\mathrm{CO}_{2}$ atmospheric transport and inverse modeling studies, $\mathrm{CO}_{2}$ emissions were released exclusively at the surface (e.g., Sarrat et al., 2009; Lauvaux et al., 2009; Broquet et al., 2011; Ganshin et al., 2012; Meesters et al., 2012; Pillai et al., 2016; Lauvaux et al., 2016; Liu et al., 2017; Graven et al., 2018; Fischer et al., 2018). In Lagrangian models such as the Stochastic Time-Inverted Lagrangian Transport model (STILT) (Lin et al., 2003) or FLEXible PARTicle dispersion model (FLEXPART) (Stohl et al., 2005), which are often used in backward, adjoint mode for inverse modeling, particles are typically sampled over a fixed vertical depth above the surface or relative to the height of planetary boundary layer to derive source sensitivities. Similar to the release of emissions at the surface in Eulerian models, this ignores the potentially different sensitivities to emissions from elevated sources.

These approaches in Eulerian and Lagrangian models are questionable given the fact that a large proportion of $\mathrm{CO}_{2}$ is released from point sources such as power plants well above the surface. Smoke stacks are in fact designed to minimize the impact on concentrations at the ground. This is particularly important during situations with stable inversions in winter or on clear nights. However, even in well-mixed conditions, an elevated release may lead to a faster dilution and different propagation of the signal due to wind speeds and directions changing with altitude.

In the air quality modeling community, the importance of vertically distributing emissions has been recognized much earlier (e.g., Houyoux et al., 2002) and is now well established, especially for species such as $\mathrm{SO}_{2}$ that are primarily emitted from power plants and industrial sources (Bieser et al., 2011; Mailler et al., 2013; Karamchandani et al., 2014; Guevara et al., 2014). Accounting for plume rise has also 
been demonstrated to be critical for biomass burning emissions (Achtemeier et al., 2011). The main goal of this study is to demonstrate that this is also critical for the simulation of atmospheric $\mathrm{CO}_{2}$ concentrations.

We employ very-high-resolution $(1.1 \mathrm{~km} \times 1.1 \mathrm{~km})$ simulations for the year 2015 conducted over a $750 \mathrm{~km} \times 650 \mathrm{~km}$ wide domain centered in the city of Berlin, Germany. The simulations included separate tracers representing $\mathrm{CO}_{2}$ emitted only at the surface and $\mathrm{CO}_{2}$ emitted according to sourcedependent vertical profiles. As the domain covered several large coal-fired power plants, we also investigate the impact of dynamically accounting for plume rise versus applying static vertical emission profiles. We focus on domainaveraged statistics rather than on individual plumes and on near-surface concentrations in the afternoon and total columns at satellite overpass time as typically used in inverse modeling. Conditions with a well-mixed and fully developed boundary layer during daytime are expected to minimize the mismatch between model and observations.

\section{Data and methods}

\subsection{COSMO-GHG model}

The Consortium for Small-scale Modeling (COSMO) is a limited-area, non-hydrostatic numerical weather prediction (NWP) model developed by the German weather service together with a consortium of seven European weather services (Baldauf et al., 2011). In addition to operational weather prediction, the model is applied widely for climate and air pollution research in various modified and extended versions (e.g., Rockel et al., 2008; Davin et al., 2011; Vogel et al., 2009; Zubler et al., 2011), making COSMO a versatile community model.

In the project CarboCount-CH (Oney et al., 2015), COSMO was extended with a module for the simulation of greenhouse gases, hereafter referred to as COSMO-GHG. The extension was built on a newly developed tracer module (Roches and Fuhrer, 2012), which replaced the previous nonuniform treatment of meteorological tracers in the model. A similar, independently developed COSMO-based $\mathrm{CO}_{2}$ model system was presented by Uebel and Bott (2018).

COSMO-GHG was first applied by Liu et al. (2017) to study the spatiotemporal patterns of fossil fuel $\mathrm{CO}_{2}$ in $\mathrm{Eu}-$ rope. They concluded that fossil fuel $\mathrm{CO}_{2}$ accounts for more than half of the total (anthropogenic plus biospheric) temporal variations in atmospheric $\mathrm{CO}_{2}$ over large parts of Europe. Furthermore, they evaluated the model against observations, demonstrating that the simulated fossil fuel variations favorably agreed with observations of fossil fuel $\mathrm{CO}_{2}$ derived from concurrent measurements of $\mathrm{CO}$ and ${ }^{14} \mathrm{CO}_{2}$.

COSMO is the first operational NWP model worldwide that is running on hardware accelerated using graphical processing units (GPUs) (Fuhrer et al., 2014). This highly effi- cient code is operationally used by the Swiss weather service MeteoSwiss and has been applied for decadal convectionresolving climate simulations (Leutwyler et al., 2017). In the framework of SMARTCARB, the modules of the GHG extension were ported to the GPU version following the concept of OpenACC compiler directives, which is a high-level approach to offload compute-intensive parts to a GPU accelerator (Lapillonne and Fuhrer, 2014). Benchmark tests showed that the GPU version achieved a speedup by a factor of 6, which allowed for an increase in spatial and time resolution, and which greatly reduced the computational (and energy) costs of the simulations conducted in this study.

\subsection{Model domain and setup}

The model simulations were conducted in the framework of the project SMARTCARB, which aimed at studying the potential benefit of adding an $\mathrm{NO}_{2}$ or $\mathrm{CO}$ channel to the instrument package of a future $\mathrm{CO}_{2}$ satellite mission with respect to quantifying $\mathrm{CO}_{2}$ emissions from strong localized sources such as cities and power plants. For this purpose, a model domain was selected covering the city of Berlin as well as several large power plants in Germany, Poland and Czech Republic. The domain extended approximately $750 \mathrm{~km}$ in the east-west and $650 \mathrm{~km}$ in the south-north directions to cover at least a complete $250 \mathrm{~km}$ wide satellite swath on either side of the city. Berlin was selected not only because it is one of the largest cities in Europe, but also because it is rather isolated, and because it has already been investigated in previous $\mathrm{CO}_{2}$ modeling and observation studies (Pillai et al., 2016; Hase et al., 2015). Simulations were conducted for the complete year 2015 at $1.1 \mathrm{~km} \times 1.1 \mathrm{~km}$ horizontal resolution and 60 vertical levels with a top at $24 \mathrm{~km}$. The lowest model layer had a thickness of $20 \mathrm{~m}$. The vertical allocation of the emissions relative to this vertical resolution of the model will be described in Sect. 2.4. The high horizontal resolution was selected to comply with the small pixel size of $2 \mathrm{~km} \times 2 \mathrm{~km}$ of the planned $\mathrm{CO}_{2}$ imaging satellite, keeping in mind that the effective resolution of Eulerian transport models is much lower than the spacing of the model grid (Kent et al., 2014).

The simulations included a total of 50 different passively transported tracers of $\mathrm{CO}_{2}, \mathrm{CO}$ and $\mathrm{NO}_{x}$. The tracers represented different sources, release times or release altitudes and included background tracers constrained at the lateral boundaries by global-scale models. Two additional tracers for biospheric fluxes (respiration and photosynthesis) were included for $\mathrm{CO}_{2}$, and four additional tracers with varying $e$-folding lifetimes of 2, 4, 12 and $24 \mathrm{~h}$ for $\mathrm{NO}_{x}$. In this study, however, we focus on only a few of these tracers, notably on the following four anthropogenic $\mathrm{CO}_{2}$ emission tracers:

- CO2_VERT: all anthropogenic emissions in the model domain released according to source-specific vertical profiles. 
- CO2_SURF: same as CO2_VERT but all emissions released at the surface, i.e., into the lowest model layer.

- CO2_PP-PR: emissions from the six largest power plants with explicit plume rise calculations.

- CO2_PP-EMEP: emissions from the six largest power plants released according to a fixed vertical emission profile.

The simulations were nested into the operational European COSMO-7 analyses of MeteoSwiss, which provided the lateral boundary conditions for meteorological variables (temperature, pressure, wind, humidity, clouds) at $7 \mathrm{~km}$ horizontal and hourly temporal resolution. Because of the relatively small domain, these boundary conditions provided a strong constraint for the meteorology within the domain. For $\mathrm{CO}_{2}$, lateral boundary conditions were obtained from a global freerunning high-resolution $\mathrm{CO}_{2}$ simulation (T1279, 137 levels, $\sim 15 \mathrm{~km}$ horizontal resolution) provided by the European Centre for Medium-Range Weather Forecasts (ECMWF) through the European Earth observation Copernicus program (Agustí-Panareda et al., 2014). The simulation was indirectly constrained by in situ data by using a global climatology of optimized biospheric fluxes computed with the $\mathrm{CO}_{2}$ assimilation system of Chevallier et al. (2010).

\subsection{Emissions and biospheric fluxes}

Anthropogenic emissions were obtained by merging the Netherlands Organisation for Applied Scientific Research European Monitoring Atmospheric Composition and Climate version 3 (TNO/MACC-3) inventory with a detailed inventory available for the city of Berlin. Dedicated municipal inventories can accurately account for the specific conditions and activities in a city and may therefore significantly deviate from inventories obtained by simple downscaling from larger-scale inventories (Timmermans et al., 2013; Gately and Hutyra, 2017).

Version 3 of the TNO/MACC inventory was used, which has an improved representation of point sources as compared to version 2 described in Kuenen et al. (2014). It has a nominal resolution of $1 / 16^{\circ} \times 1 / 8^{\circ}$ (approximately $7 \mathrm{~km} \times 7 \mathrm{~km}$ ) but additionally reports the emissions from strong point sources at their exact location. Emissions are provided separately for different source categories following the Standardized Nomenclature for Air Pollutants (SNAP) classification (European Environment Agency, 2002). The emissions of the year 2011 were taken, which was the most recent year available from the inventory.

The city of Berlin has developed a very detailed inventory for about 30 air pollutants and greenhouse gases for seven major source categories. The inventory was provided in a Geographic Information System (GIS) format as a collection of shape files representing individual area, point and line sources. The latest available year was 2012. In our simulations, separate tracers were included for three broad source groups: traffic, industry and heating. The attribution of the 10 SNAP categories in TNO/MACC-3 and the seven source categories in the Berlin inventory to these groups are described in detail in the final report of the SMARTCARB project (Kuhlmann et al., 2019).

Both inventories were projected onto the COSMO model grid (rotated latitude-longitude grid with the North Pole at $43^{\circ} \mathrm{N}$ and $10^{\circ} \mathrm{W}, 0.01^{\circ} \times 0.01^{\circ}$ resolution) using massconservative methods. Point sources were placed into the proper COSMO grid cell. As a last step, the two inventories were merged using a mask for the city of Berlin. The merged emission $e$ per grid cell was estimated as $e=(1-f) e_{\mathrm{TNO}}+$

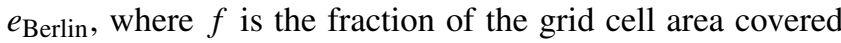
by Berlin.

Figure 1 presents a map of the $\mathrm{CO}_{2}$ inventory of Berlin in the original format and after projection onto the COSMO grid. The rasterized map reveals 22 strong $\mathrm{CO}_{2}$ point sources, which together account for $41 \%$ of the total emissions in the city. The two horizontal stripes correspond to the paths of airplanes taking off and landing at the two main airports.

In order to calculate hourly emissions as input for the model simulations, temporal scaling factors were applied describing diurnal, day-of-week and seasonal variations. The same temporal profiles were used as in Liu et al. (2017), which are based on factors originally developed for air pollution modeling (Builtjes et al., 2003). These profiles depend on SNAP category and, except for diurnal profiles, on country. Diurnal profiles were matched to the local time of Germany.

Biospheric $\mathrm{CO}_{2}$ fluxes due to gross photosynthetic production and respiration were computed at the resolution of the COSMO model using the Vegetation Photosynthesis and Respiration (VPRM) model (Mahadevan et al., 2008). This diagnostic model is based on meteorological input ( $2 \mathrm{~m}$ temperature and downward shortwave radiation at the surface) along with the Enhanced Vegetation Index (EVI) and Land Surface Water Index (LSWI) calculated from MODIS satellite reflectances. These indices were available as an 8-day product (MOD09A1, V006) at $500 \mathrm{~m}$ spatial resolution. Vegetation classes were determined from the $1 \mathrm{~km}$ SYNMAP land cover map (Jung et al., 2006). Model parameter values describing the fluxes from different vegetation types were taken from a previous study (Kountouris et al., 2018), in which they were optimized using data from 47 European eddy covariance measurement sites for the year 2007. The model was run offline for the entire year 2015, driven by the highest resolution ECMWF meteorological data available.

\subsection{Vertical allocation of emissions and plume rise}

Emissions were distributed in the vertical using sourcespecific profiles developed for the European Monitoring and Evaluation Program (EMEP) (see, e.g., Bieser et al., 2011). For the purpose of the present study, the number of vertical layers was increased from 7 to 10 to enable a finer allocation 

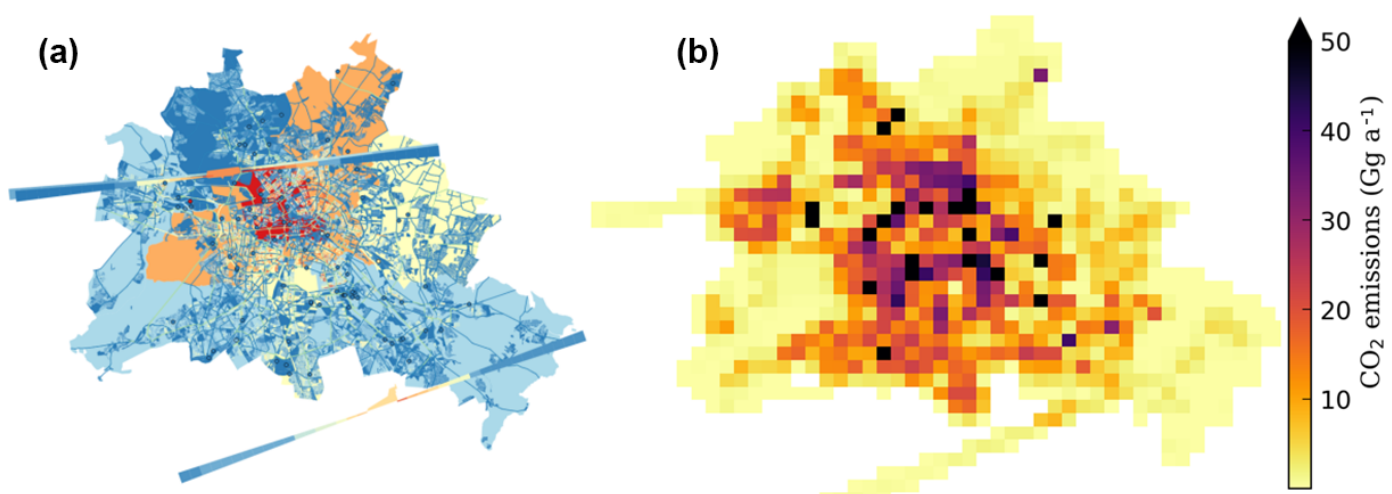

Figure 1. (a) Schematic of $\mathrm{CO}_{2}$ emissions in the Berlin inventory with point, line and area sources from different emission categories. Point, line and area sources are in different units (in $\mathrm{kg} \mathrm{s}^{-1}$ for point, $\mathrm{kg} \mathrm{s}^{-1} \mathrm{~m}^{-1}$ for line and $\mathrm{kg} \mathrm{s}^{-1} \mathrm{~m}^{-2}$ for area sources) each being colored separately between minimum and maximum values. (b) Total $\mathrm{CO}_{2}$ emissions re-projected and rasterized onto the COSMO model grid.

to the model layers of COSMO-GHG. Specifically, the layers 4-90 $\mathrm{m}$ and $90-170 \mathrm{~m}$ of the original EMEP profiles were divided into three and two sublayers, respectively. The attribution of emissions to these sublayers was done in a rough way, for example, by placing a larger proportion of emissions from "combustion in manufacturing industry" into the upper parts but distributing emissions from "non-industrial (residential) combustion" rather evenly over the three layers between 4 and $90 \mathrm{~m}$, considering that industrial sources are likely to emit at higher altitudes. The profile for SNAP 9 (waste) was modified in two ways: (i) by moving $10 \%$ from higher layers to the lowest layer to account for $\mathrm{CO}_{2}$ emissions from landfills and waste water treatment plants, and (ii) by moving the large fractions originally placed into the layers $170-310 \mathrm{~m}$ (40\%) and 310-470 m (35\%) into lower layers between 90 and $310 \mathrm{~m}$. This latter modification was made following the study of Pregger and Friedrich (2009), which showed that the emission-weighted height of waste incinerator stacks in Germany is only about $100 \mathrm{~m}$ and that $90 \%$ of the corresponding emissions including plume rise are expected to occur below $300 \mathrm{~m}$.

The modified EMEP profiles are presented in Table 2 and illustrated in Fig. 2a. They were only applied to point sources such as power plants and large industrial facilities. A different set of profiles with lower average emission heights was applied to area sources, as these represent much weaker and more dispersed sources. The corresponding profiles are presented in Table 3 and Fig. 2b. The motivation for this distinction is best illustrated for SNAP category 2, residential and other non-industrial heating. In the case of point sources, these are large heating facilities such as combined heat and power plants with tall stacks. In the case of area sources, in contrast, these are mostly private heating systems releasing $\mathrm{CO}_{2}$ through chimneys at roof level. This is reflected in our profiles for SNAP 2 area sources being limited to the layers between 4 and $60 \mathrm{~m}$ above surface.
As noted by Bieser et al. (2011), the EMEP profiles are based on very limited information originally collected for the city of Zagreb, Croatia. They therefore proposed a different set of profiles based on plume rise calculations for a large number of point sources across Europe. Their study indicated that the vertical placement of emissions in the EMEP profiles is too high for combustion processes (SNAP 1, 2, 3 and 9) but too low for production processes (SNAP 4 and 5). For SNAP 1 (power plants), for example, they proposed a median release height of about $300 \mathrm{~m}$, whereas the median in the EMEP profiles is about $400 \mathrm{~m}$.

Although we did not apply the profiles of Bieser et al. (2011), our modification of SNAP 9 and the distinction between point and area sources effectively reduces the emission heights of $\mathrm{CO}_{2}$ compared to the standard EMEP profiles. Furthermore, for the 22 largest point sources in Berlin as well as the six largest power plants in the model domain in Germany (Jänschwalde, Lippendorf, Boxberg, Schwarze Pumpe) and Poland (Turów, Pątnów), the static EMEP SNAP 1 profiles were replaced by dynamic plume rise simulations for each hour of the year.

The effective emission height can be much higher than the geometric height of a stack because of the momentum and buoyancy of the flue gas. In general, plume rise depends on stack geometry (height and diameter), flue gas properties (temperature, humidity, exit velocity) and meteorological conditions (wind speed, atmospheric stability). Plume rise and the vertical extent of the plumes were calculated using the empirical equations recommended by the Association of German Engineers (VDI - Fachbereich Umweltmeteorologie, 1985), which are based on the original work of Briggs (1984). Hourly profiles of wind and temperature for the year 2015 were extracted from the COSMO-7 analyses of MeteoSwiss at the locations of the individual stacks. For power plants outside Berlin, typical stack and flue gas parameters were mainly taken from published statistics for Germany (Pregger and Friedrich, 2009), since these param- 
(a)

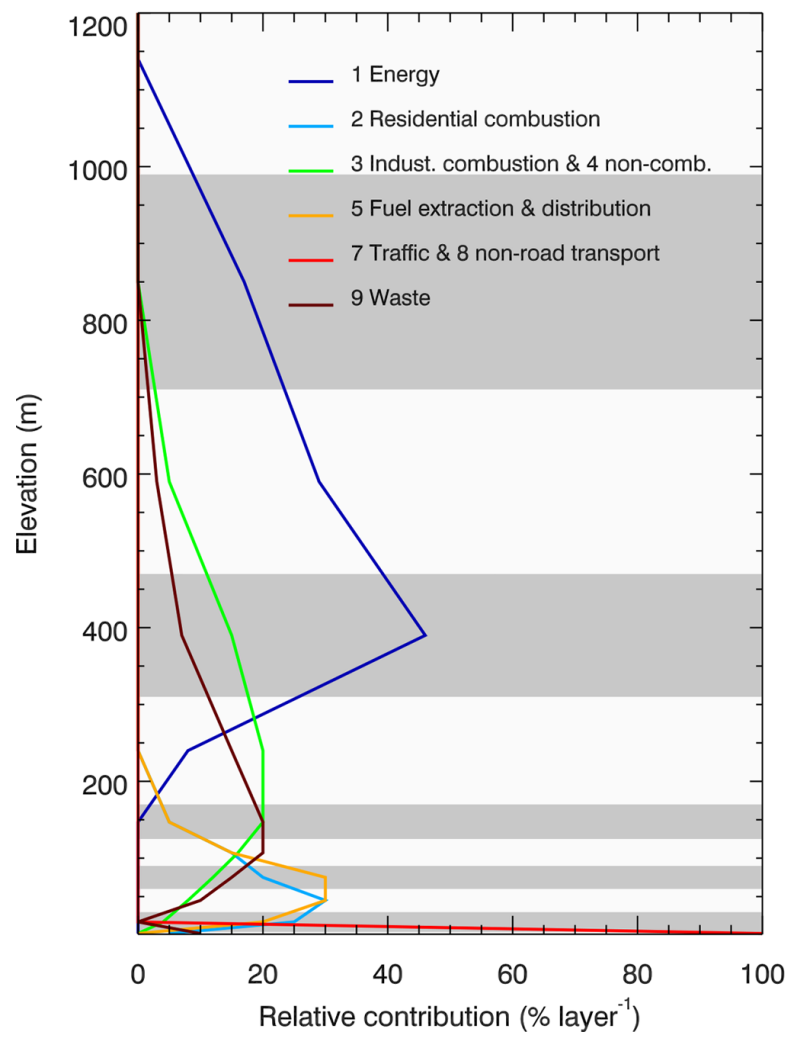

(b)

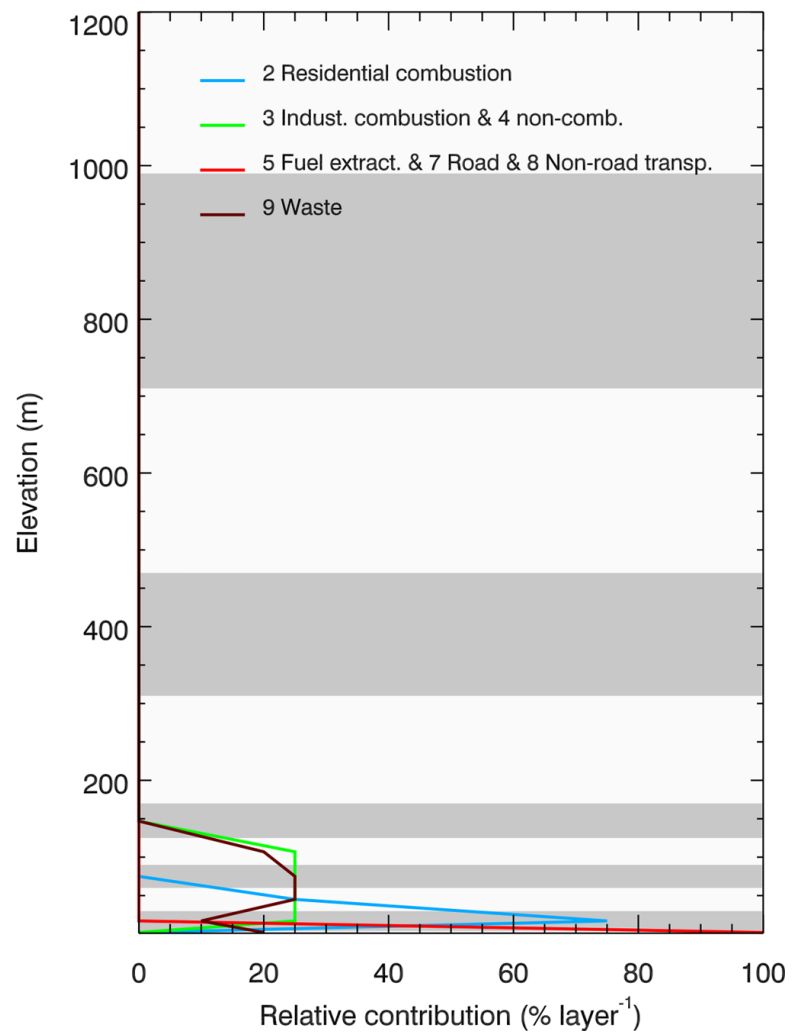

Figure 2. Vertical emission profiles applied for (a) point sources and (b) area/line sources. The alternating gray and white backgrounds denote the vertical layers.

Table 1. Stack parameters used for plume rise calculation for the six largest power plants in the model domain.

\begin{tabular}{lrrrrr}
\hline Name & $\begin{array}{r}\text { Longitude } \\
\left({ }^{\circ} \mathrm{E}\right)\end{array}$ & $\begin{array}{r}\text { Latitude } \\
\left({ }^{\circ} \mathrm{N}\right)\end{array}$ & $\begin{array}{r}\text { Stack } \\
\text { height }(\mathrm{m})\end{array}$ & $\begin{array}{r}\text { Effluent } \\
\text { temperature }^{\mathrm{a}}(\mathrm{K})\end{array}$ & $\begin{array}{r}\text { Volume flux }^{\mathrm{b}} \\
\left(\mathrm{m}^{3} \mathrm{~s}^{-1}\right)\end{array}$ \\
\hline Jänschwalde & 14.458 & 51.837 & $120^{\mathrm{b}}$ & 322 & 790 \\
Lippendorf & 12.372 & 51.184 & $175^{\mathrm{b}}$ & 322 & 790 \\
Schwarze Pumpe & 14.354 & 51.538 & $141^{\mathrm{b}}$ & 322 & 790 \\
Boxberg & 14.569 & 51.418 & $155^{\mathrm{b}}$ & 322 & 790 \\
Turów & 14.911 & 50.948 & $150^{\mathrm{a}}$ & 416 & 159 \\
Pątnów & 18.238 & 52.303 & $114^{\mathrm{a}}$ & 447 & 59 \\
\hline
\end{tabular}

a Average parameters by fuel and plant capacity taken from Pregger and Friedrich (2009). ${ }^{\mathrm{b}}$ https:

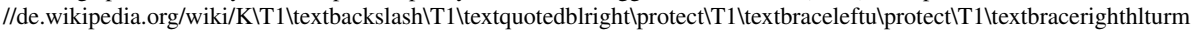
(last access: 28 August 2018).

eters are not publicly available (see Table 1). For stacks in Berlin, parameters were included in the emission inventory provided by the city of Berlin.

Two complicating factors were not considered in the present study. The European standards for large combustion plants (http://data.europa.eu/eli/dec_impl/2017/1442/oj, last access: 26 March 2019) require the flue gas to be cleaned for sulfur and nitrogen oxides. As a consequence of the chemical washing process, the temperature of the flue gas is reduced to a level where it can no longer be released via a classical smoke stack (Busch et al., 2002). In order to avoid reheating, the flue gas is often directed to the cooling tower and mixed into its moist buoyant air stream. This is true for the major German power plants in the domain, whereas the power plants Turów and Pątnów in Poland were, to the best of our knowledge, still equipped with smoke stacks in 2015. Plume rise computations are much more complex in the case of cooling towers due to latent heat release and 
Table 2. Vertical emission profiles for point sources for different SNAP categories as fractions of the total emitted mass per vertical layer. Layers are denoted by their lower and upper limits (meters above ground).

\begin{tabular}{llrrrrrrrrrr}
\hline SNAP & Description & $0-4$ & $4-30$ & $30-60$ & $60-90$ & $90-125$ & $125-170$ & $170-310$ & $310-470$ & $470-710$ & $710-990$ \\
\hline 1 & Energy industry & 0.00 & 0.00 & 0.00 & 0.00 & 0.00 & 0.00 & 0.08 & 0.46 & 0.29 & 0.17 \\
\hline 2 & Non-industrial combustion & 0.05 & 0.25 & 0.30 & 0.20 & 0.15 & 0.05 & 0.00 & 0.00 & 0.00 & 0.00 \\
\hline 3 & $\begin{array}{l}\text { Combustion in manufacturing } \\
\text { industry }\end{array}$ & 0.00 & 0.04 & 0.08 & 0.12 & 0.16 & 0.20 & 0.20 & 0.15 & 0.05 & 0.00 \\
\hline 4 & Production processes & 0.00 & 0.20 & 0.30 & 0.30 & 0.15 & 0.05 & 0.00 & 0.00 & 0.00 & 0.00 \\
\hline 5 & $\begin{array}{l}\text { Extraction/distribution of } \\
\text { fossil fuels }\end{array}$ & 0.00 & 0.20 & 0.30 & 0.30 & 0.15 & 0.05 & 0.00 & 0.00 & 0.00 & 0.00 \\
\hline 6 & Product use & 0.50 & 0.50 & 0.00 & 0.00 & 0.00 & 0.00 & 0.00 & 0.00 & 0.00 & 0.00 \\
\hline 7 & Road transport & 1.00 & 0.00 & 0.00 & 0.00 & 0.00 & 0.00 & 0.00 & 0.00 & 0.00 & 0.00 \\
\hline 8 & Non-road transport & 1.00 & 0.00 & 0.00 & 0.00 & 0.00 & 0.00 & 0.00 & 0.00 & 0.00 & 0.00 \\
\hline 9 & Waste treatment & 0.10 & 0.00 & 0.10 & 0.15 & 0.20 & 0.20 & 0.15 & 0.07 & 0.03 & 0.00 \\
\hline 10 & Agriculture & 1.00 & 0.00 & 0.00 & 0.00 & 0.00 & 0.00 & 0.00 & 0.00 & 0.00 & 0.00 \\
\hline
\end{tabular}

Table 3. Vertical emission profiles for area sources for different SNAP categories as fractions of the total emitted mass per vertical layer. Layers are denoted by their lower and upper limits (meters above ground). Emissions in SNAP 1 are released exclusively from point sources.

\begin{tabular}{llrrrrrrrrrr}
\hline SNAP & Description & $0-4$ & $4-30$ & $30-60$ & $60-90$ & $90-125$ & $125-170$ & $170-310$ & $310-470$ & $470-710$ & $710-990$ \\
\hline 1 & Energy industry & - & - & - & - & - & - & - & - & - \\
\hline 2 & Non-industrial combustion & 0.00 & 0.75 & 0.25 & 0.00 & 0.00 & 0.00 & 0.00 & 0.00 & 0.00 & 0.00 \\
\hline 3 & $\begin{array}{l}\text { Combustion in manufacturing } \\
\text { industry }\end{array}$ & 0.00 & 0.25 & 0.25 & 0.25 & 0.25 & 0.00 & 0.00 & 0.00 & 0.00 & 0.00 \\
\hline 4 & Production processes & 0.00 & 0.25 & 0.25 & 0.25 & 0.25 & 0.00 & 0.00 & 0.00 & 0.00 & 0.00 \\
\hline 9 & Waste treatment & 0.20 & 0.10 & 0.25 & 0.25 & 0.20 & 0.00 & 0.00 & 0.00 & 0.00 & 0.00 \\
\hline $5-8,10$ & Other categories & 1.00 & 0.00 & 0.00 & 0.00 & 0.00 & 0.00 & 0.00 & 0.00 & 0.00 & 0.00 \\
\hline
\end{tabular}

the interaction with moisture in the ambient air (Schatzmann and Policastro, 1984). The additional release of latent heat may enhance plume rise by $20 \%$ to $100 \%$ compared to a dry plume (Hanna, 1972). Second, large power plants such as Jänschwalde are equipped with multiple cooling towers a short distance from each other. Their plumes tend to interact in a way that enhances plume rise, an effect that additionally depends on the alignment of the towers relative to the flow direction (Bornoff and Mokhtarzadeh-Dehghan, 2001). Neglecting these effects may thus underestimate true plume rise in our calculations.

\section{Results}

\subsection{Plume rise at power plants}

An example for the results of the plume rise simulations are presented for Jänschwalde, the largest power plant in the domain. Figure 3 a shows the hourly evolution of the plume cen- ter heights during the year 2015. Plumes typically rise 100 to $400 \mathrm{~m}$ above the top of the cooling tower, but occasionally much further when both winds and atmospheric stability are low. Plume rise varies strongly from day to day and shows a pronounced seasonal cycle. Plumes rise on average to $360 \mathrm{~m}$ above ground in summer but only to $250 \mathrm{~m}$ in winter. Due to the diurnal evolution of the PBL, plume rise also varies with the hour of the day, except during winter. In summer, the amplitude of this diurnal variability is about $150 \mathrm{~m}$, with a broad minimum at night from 21:00 to 08:00 LT (19:00 to 06:00 UTC) and a peak in the early afternoon.

Figure 4 compares the histograms of plume rise at Jänschwalde in summer and winter to the standard EMEP SNAP 1 profile of Fig. 2. In agreement with Bieser et al. (2011), the computed profiles tend to place emissions significantly lower compared to EMEP, even in summer. Median and mean effective emission heights in 2015 were 266 and $310 \mathrm{~m}$ above ground, respectively. For the smaller power plant (Lippendorf), these numbers were 187 and $210 \mathrm{~m}$. Simulated plume rise for these two power plants was thus at least 
(a)

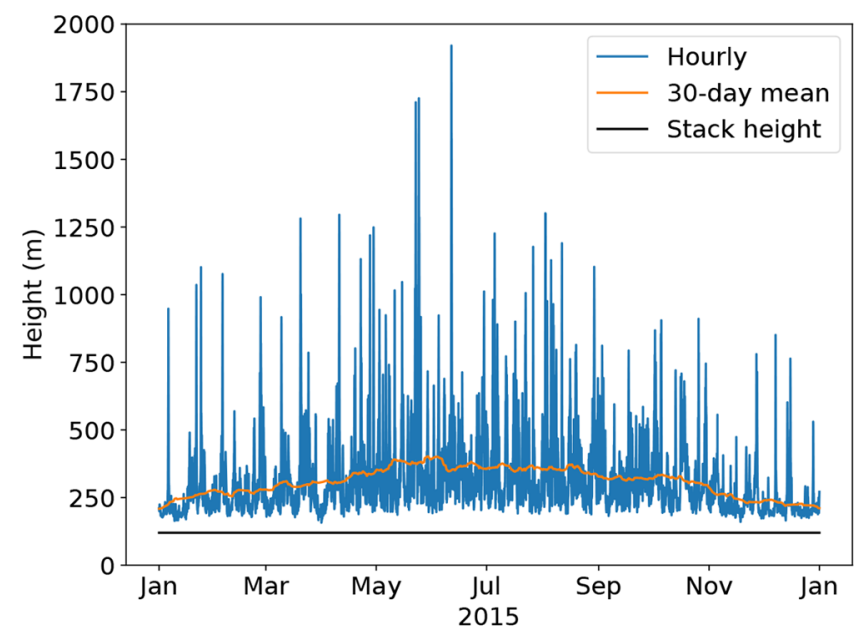

(b)

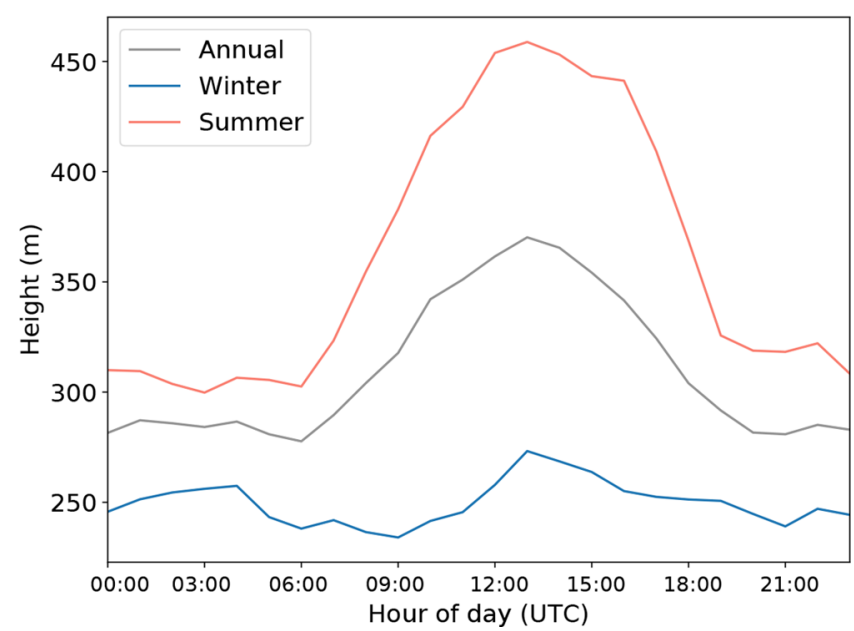

Figure 3. Effective $\mathrm{CO}_{2}$ emission heights at the power plant in Jänschwalde, Germany, based on plume rise calculations. (a) Hourly plume rise in 2015. The orange line is a 30-day moving average. The black solid line denotes the height of the cooling tower (120 m). (b) Mean annual, winter (DJF) and summer (JJA) diurnal cycles.

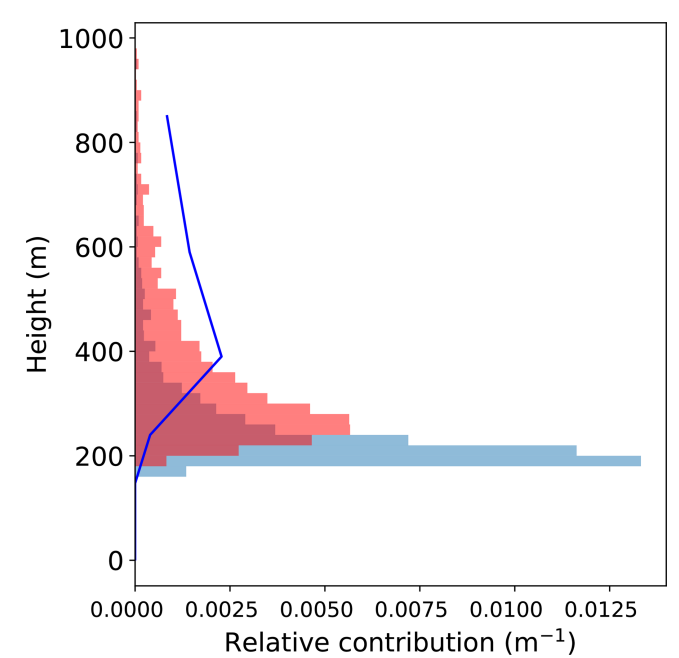

Figure 4. Normalized histogram of plume altitude above ground at the Jänschwalde power plant in winter (blue) and summer (red). The blue line shows the EMEP standard profile for power plants for comparison. Areas below the curves integrated along the vertical axis are normalized to 1 .

$100 \mathrm{~m}$ lower compared to the EMEP profile. The large fraction of emissions placed above $500 \mathrm{~m}$ in the EMEP profile seems particularly unrealistic. Our plume rise calculations are more consistent with the profiles recommended by Bieser et al. (2011).

\subsection{Emission profiles over Berlin}

The main emission sources of $\mathrm{CO}_{2}$ in Berlin are "traffic", "private households and public buildings", "industry", "trade and others" and the "transformation sector" which includes large facilities for heat and electricity production. In 2015, traffic only accounted for $29 \%$ of all emissions, households and industry for $27 \%$ (Amt für Statistik Berlin-Brandenburg, 2018). By far the largest single source was the transformation sector with a share of $42 \%$ of the total. As a result, a significant fraction of emissions is released through stacks.

Figure 5 shows the monthly mean vertical profiles of $\mathrm{CO}_{2}$ emissions from Berlin in a winter month (February) and a summer month (August) as used in our simulations. The profiles reflect the superposition of emissions from different sectors with different vertical profiles (see Fig. 2) and different seasonal contributions. In February, for example, residential heating is an important source between 4 and $60 \mathrm{~m}$ above ground, whereas emissions in these layers are almost completely absent in August. Although in both months the profiles have a pronounced peak at the surface, $36 \%$ of $\mathrm{CO}_{2}$ is released above $90 \mathrm{~m}$ in February, with that share rising to $58 \%$ in August when residential heating is low. These numbers suggest that a proper vertical allocation of emissions is important even in cities.

The vertical profiles of the emissions of $\mathrm{CO}$ and $\mathrm{NO}_{x}$ are overlaid in Fig. 5 for comparison, since coincident measurements of $\mathrm{NO}_{2}$ or $\mathrm{CO}$ may be used by a future $\mathrm{CO}_{2}$ satellite for emission quantification. Both $\mathrm{CO}$ and $\mathrm{NO}_{x}$ have a more pronounced peak at the surface due to the larger proportion of traffic emissions. Similar to $\mathrm{CO}_{2}$, a large (albeit smaller) fraction of $\mathrm{NO}_{x}$ is emitted well above ground by large point sources. Interestingly, these sources emit very little $\mathrm{CO}$, suggesting efficient combustion or cleaning of the exhaust. The fraction of $\mathrm{CO}$ released above $90 \mathrm{~m}$ is below $5 \%$, in sharp contrast to $\mathrm{CO}_{2}$. 
(a)

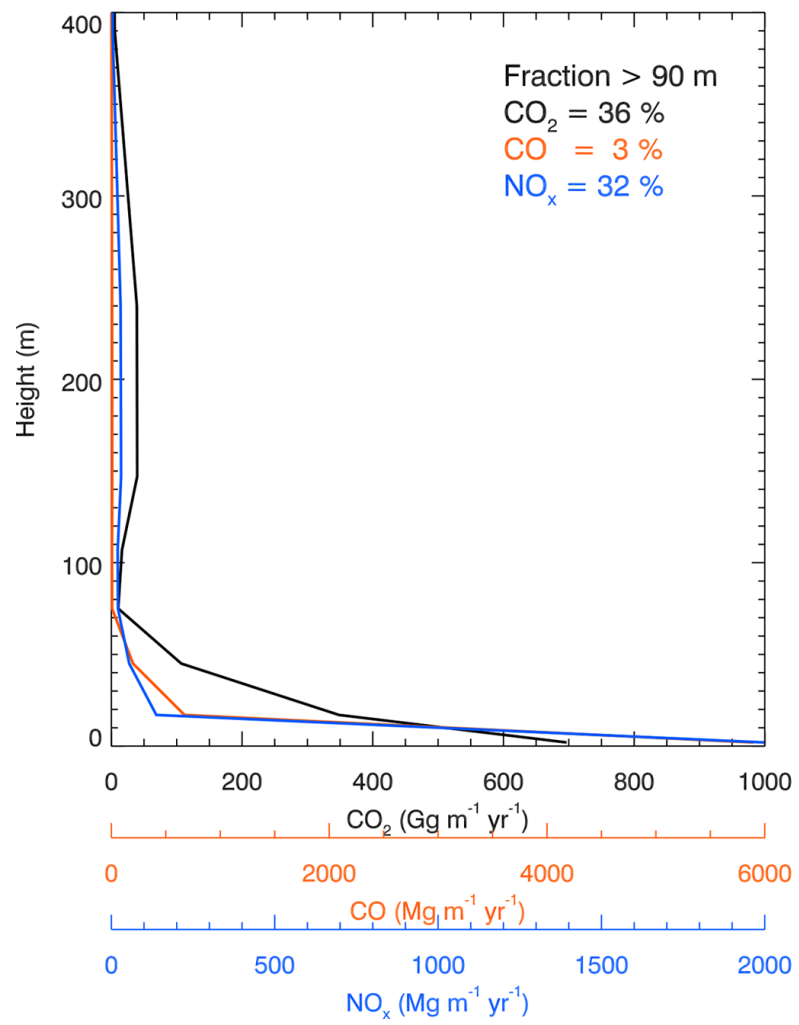

(b)

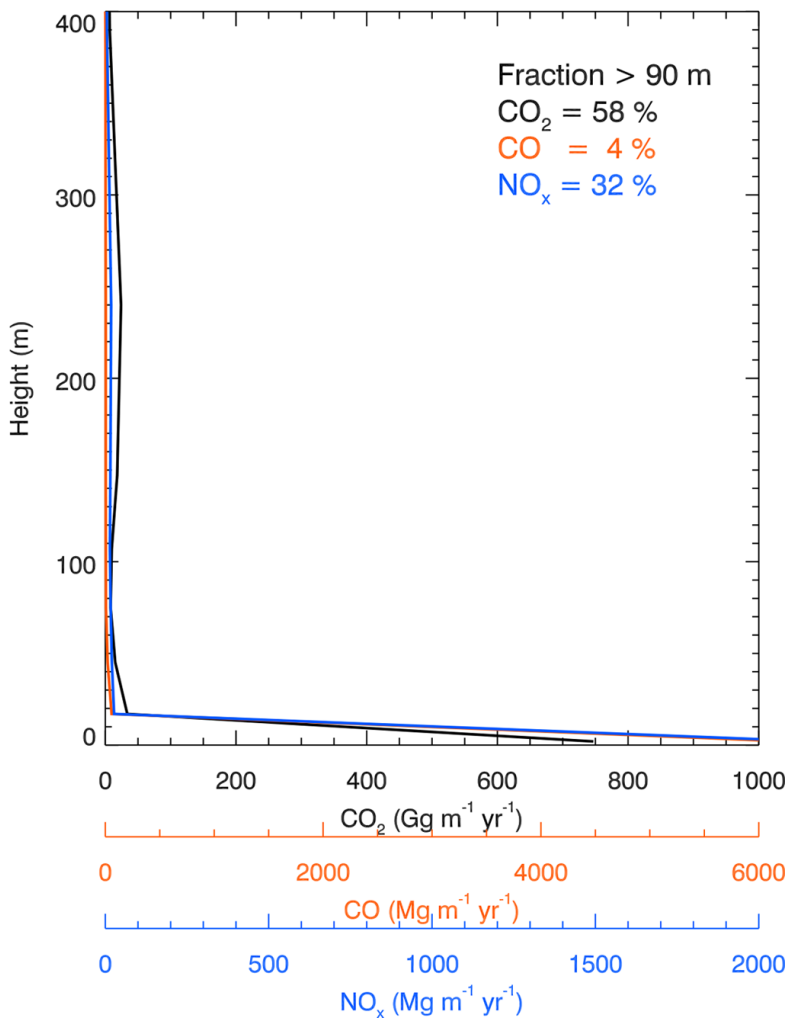

Figure 5. Monthly mean vertical emission profiles of $\mathrm{CO}_{2}, \mathrm{CO}$ and $\mathrm{NO}_{x}$ over Berlin in (a) February and (b) August.

\section{3 $\mathrm{CO}_{2}$ at the surface}

Maps of the monthly mean afternoon $\mathrm{CO}_{2}$ dry air mole fractions (hereafter referred to as "concentrations") in the lowest model layer $(0-20 \mathrm{~m})$ from all anthropogenic emissions within the model domain are presented in Fig. 6 for January and July, respectively. Afternoon values were selected since current inversion systems usually assimilate only observations in the afternoon when vertical concentration gradients are smallest (e.g., Peters et al., 2010). Figure 6a and c show the results for the tracer CO2_VERT, with vertically distributed emissions, while Fig. $6 \mathrm{~b}$ and d show the tracer CO2_SURF, with all emissions concentrated at the surface. For all power plants labeled in the figure, plume rise was explicitly simulated for the tracer CO2_VERT.

The concentrations are generally higher in January than in July due to higher emissions and reduced vertical mixing in winter. The concentrations are also significantly higher when all $\mathrm{CO}_{2}$ is released at the surface. The main reason for these differences are power plants and other point sources, which stand out prominently in the maps for the tracer CO2_SURF but not for CO2_VERT.

As shown in Fig. 7, the differences are much larger in winter than in summer. In summer, power plant emissions are mixed efficiently over the depth of the afternoon PBL. Since this mixing is not instantaneous, differences are noticeable close to the sources but fade out rapidly with increasing distance. In winter, conversely, when vertical mixing is weak, the differences between the two tracers remain well above $1 \mathrm{ppm}$ over distances of a few tens of kilometers downstream, occasionally over $100 \mathrm{~km}$ or more.

Domain-averaged monthly mean diurnal cycles of the two tracers are presented in Fig. 8 for the months of January and July. Consistent with the maps, the concentrations of CO2_SURF are significantly higher than those of CO2_VERT. This difference is around $1.6 \mathrm{ppm}$ in January and almost constant during the day. The variations during the day appear to be dominated by the diurnal cycle of the emissions rather than by the dynamics of the PBL.

In summer, the differences are generally smaller and exhibit a pronounced diurnal cycle. Differences are about $1 \mathrm{ppm}$ at night and almost vanish (about $0.1 \mathrm{ppm}$ ) in the afternoon. Due to the low PBL at night, the concentrations increase overnight despite relatively low emissions. This increase is much more pronounced for tracer CO2_SURF, which is susceptible to surface emissions from point sources that do not stop at night. The tracer CO2_VERT only shows a marked increase during the early morning hours when traffic increases and the PBL is still low. Emissions from point sources, on the other hand, are likely released above 
(a) $\mathrm{CO}_{2}$ VERT in January

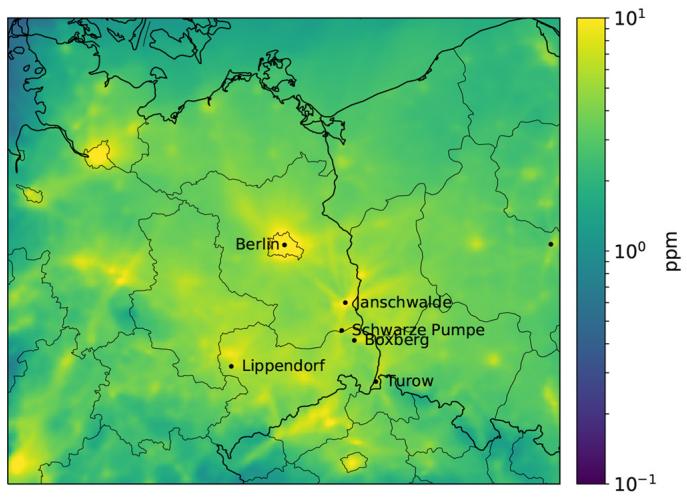

(c) $\mathrm{CO}_{2}$-VERT in July

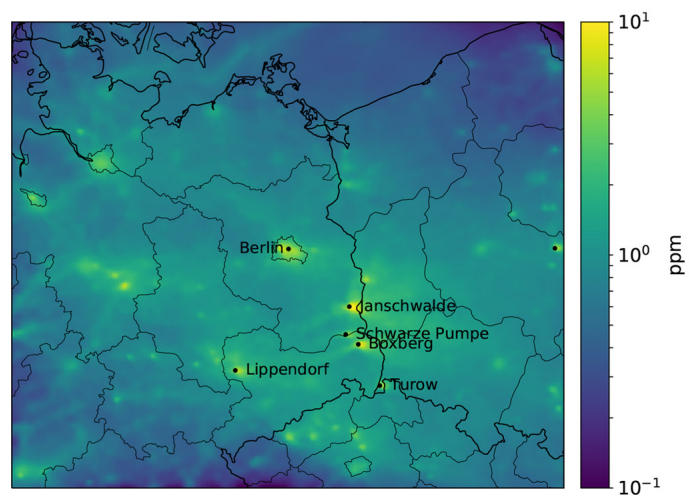

(b) $\mathrm{CO}_{2}-\mathrm{SURF}$ in January

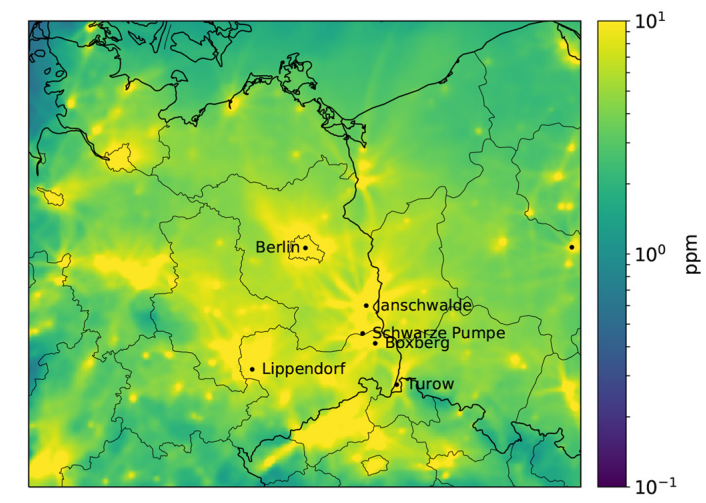

(d) $\mathrm{CO}_{2}-\mathrm{SURF}$ in July

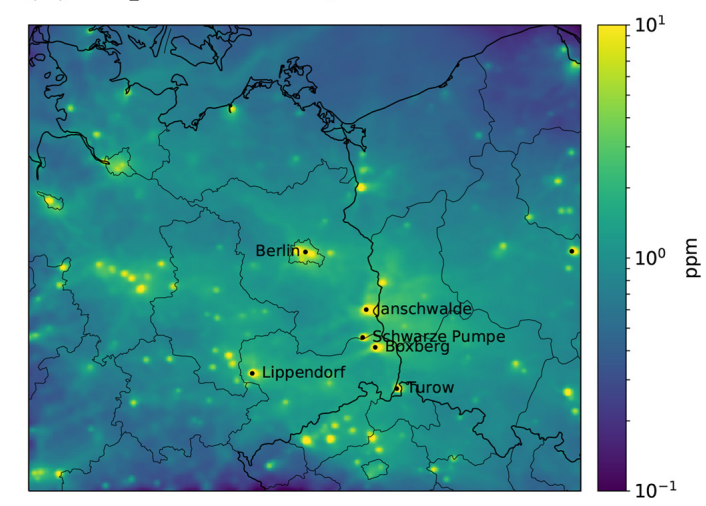

Figure 6. Mean afternoon (14:00-16:00 LT) near-surface $\mathrm{CO}_{2}$ in (a, b) January and (c, d) July contributed by all anthropogenic sources in the domain. (a, c) Tracer CO2_VERT released according to realistic vertical profiles. (b, d) Tracer CO2_SURF released only at the surface.

(a) January

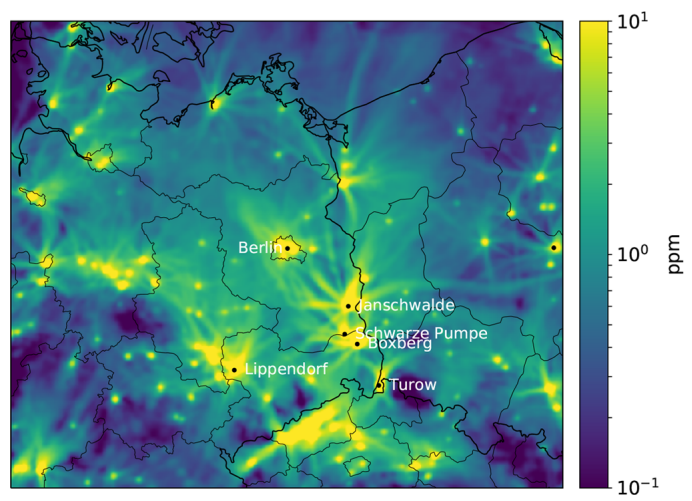

(b) July

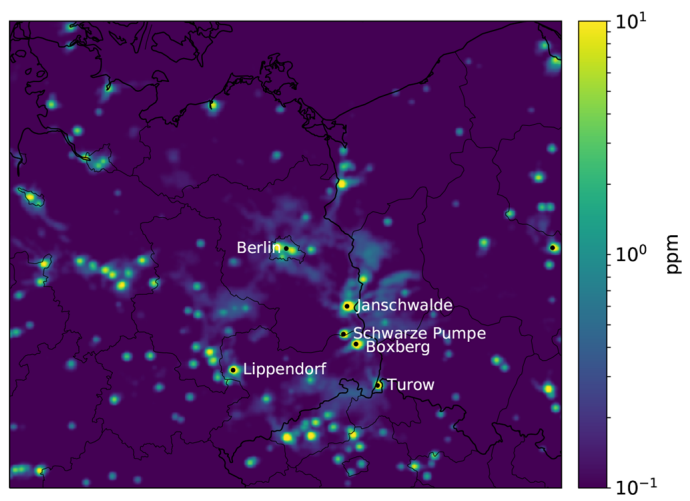

Figure 7. Difference in mean afternoon (14:00-16:00 LT) near-surface $\mathrm{CO}_{2}$ between tracers CO2_SURF and CO2_VERT in (a) January and (b) July.

the nocturnal PBL, leading to marked differences between CO2_VERT and CO2_SURF at night.

Statistics of the afternoon concentrations of the two $\mathrm{CO}_{2}$ tracers are summarized in Table 4 in terms of mean values and different percentiles of the frequency distribution. Domain-averaged $\mathrm{CO}_{2}$ concentrations are $43 \%$ higher in January when all $\mathrm{CO}_{2}$ is released at the surface compared to when emissions are distributed vertically. The differences are larger for the high percentiles, suggesting that background values are less affected than peak values. This is understandable as vertical mixing tends to reduce the differences with increasing distance from the sources. In summer, the differences are generally much smaller, but as suggested in Fig. 8, this is only true for afternoon concentrations. Mean differ- 


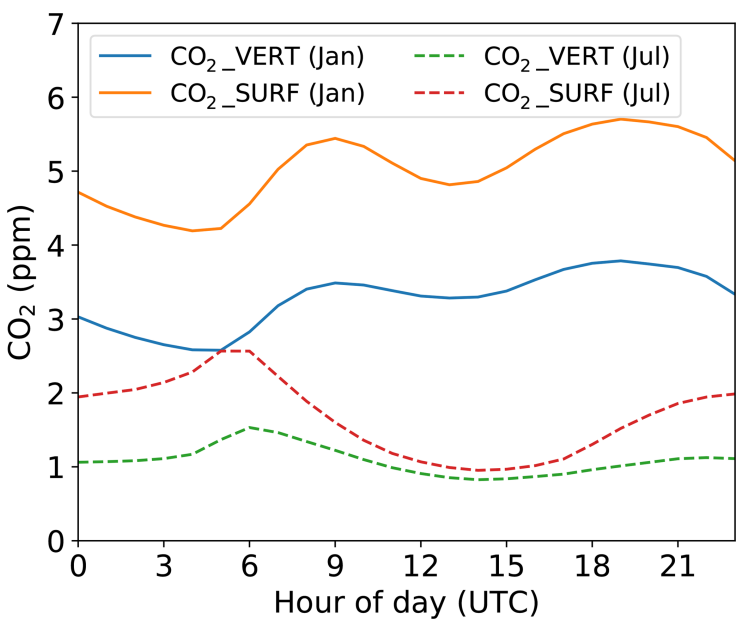

Figure 8. Mean diurnal cycles of the tracers CO2_VERT and CO2_SURF in January and July.

ences in the afternoon are of the order of $14 \%$. Again, higher percentiles tend to show larger differences. The impact on observations from tall tower networks measuring $\mathrm{CO}_{2}$ some 100 to $300 \mathrm{~m}$ above the surface (Bakwin et al., 1995; Andrews et al., 2014) will likely be somewhat smaller than suggested by the numbers above, especially in winter when the atmosphere is less well mixed.

\subsection{Column-averaged dry air mole $\mathrm{XCO}_{2}$ fractions}

As shown in the previous section, the choice of vertical allocation of the emissions has a large impact on groundlevel concentrations. Since the tracers $\mathrm{CO} 2$ _VERT and $\mathrm{CO} 2$ SURF are based on the same mass of $\mathrm{CO}_{2}$ emitted into the atmosphere and only differ by the vertical placement of this mass, differences in column-averaged dry air mole fractions (ratio of moles of $\mathrm{CO}_{2}$ to moles of dry air in the vertical column, $\mathrm{XCO}_{2}$ ) are expected to be small. However, since wind speeds tend to increase with altitude, $\mathrm{CO}_{2}$ emitted at higher levels is more likely to be transported away from the sources and leave the model domain more rapidly.

Maps of $\mathrm{XCO}_{2}$ and of the differences between the two tracers are presented in Figs. 9 and 10 in the same way as for the surface concentrations. Instead of presenting mean afternoon values, the figures show the situation at 11:30 LT (the average of output at 10:00 and 11:00 UTC) corresponding to the expected overpass time of the planned European satellites. Note that we did not account for daylight savings time in the diurnal cycles of emissions but assumed a constant offset of $+1 \mathrm{~h}$ between local time in the domain and UTC. Differences in $\mathrm{XCO}_{2}$ between the two tracers are indeed much smaller than the differences in surface concentrations, suggesting that total column observations are much less sensitive to the vertical placement of emissions. However, differences are not negligible, especially in winter (Fig. 10). The largest differences in January are seen in the northern parts of Czech Republic, which is the main coal-mining region of the country featuring a large number of power plants. Since plume rise was not explicitly calculated, $\mathrm{CO} 2$ _VERT emissions from these power plants followed the EMEP profiles, which tend to place emissions too high, as mentioned earlier. Differences over the power plants with explicit plume rise are smaller, but not negligible, with values around $1 \mathrm{ppm}$ close to the sources.

Domain-averaged mean diurnal cycles are presented in Fig. 11 and overall statistics in Table 4. Similar to the results for near-surface concentrations, the differences are larger in winter than in summer. In contrast to the situation at the surface, the differences in $\mathrm{XCO}_{2}$ remain fairly constant over the day not only in winter but also in summer. Relative differences in mean $\mathrm{XCO}_{2}$ are only $7.7 \%$ in January (compared to $43 \%$ at the surface) and $4.8 \%$ in July (compared to $14 \%$ at the surface). Note that the differences in the columns are related to the synthetic nature of our model experiment, since no anthropogenic $\mathrm{CO}_{2}$ emissions are advecting into the domain from sources outside. Nevertheless, the analysis reveals significant differences in the contributions from sources within the domain, which is the information used by any regional inverse modeling system. Consistent with the findings for near-surface concentrations, the differences tend to increase for higher percentiles, reaching about $10 \%$ at the 95th percentile (see last column in Table 4).

Although differences in monthly mean $\mathrm{XCO}_{2}$ values are relatively small, the differences can be very large at a given location and time, as illustrated in Fig. 12 for 2 July 2015. The figure shows the differences in $\mathrm{XCO}_{2}$ between two $\mathrm{CO}_{2}$ tracers representing emissions from the largest power plants in the domain. The two tracers were released either using explicit plume rise simulations (CO2_PP-PR) or according to EMEP SNAP 1 profiles (CO2_PP-EMEP). No powerplant-only tracer was simulated with emissions at the surface. Plume rise was rather moderate (to about $340 \mathrm{~m}$ above ground) at this time due to pronounced easterly winds. The red (positive) parts in the figure correspond to plumes produced by CO2_PP-PR, whereas the blue parts (negative) correspond to the tracer CO2_PP-EMEP.

Due to wind directions changing with altitude and due to the different emission heights of the tracers, the plumes are transported in different directions. Spiraling wind directions are typical of the boundary layer where winds near the surface have an ageostrophic, cross-isobaric component due to surface friction, while winds become increasingly geostrophic at higher levels. This is known as the Ekman spiral. The plumes of CO2_PP-EMEP show a stronger lateral dispersion because the tracer is released over a large vertical extent (blue line in Fig. 2). The vertical cross-section transecting the plumes about 15 to $30 \mathrm{~km}$ downwind of the sources suggests that both tracers are partially mixed over the full depth of the boundary layer at this distance, but that the centers of the plumes are clearly higher above the surface for the tracer CO2_PP-EMEP than for CO2_PP-PR. 
(a) $\mathrm{CO}_{2}$-VERT in January

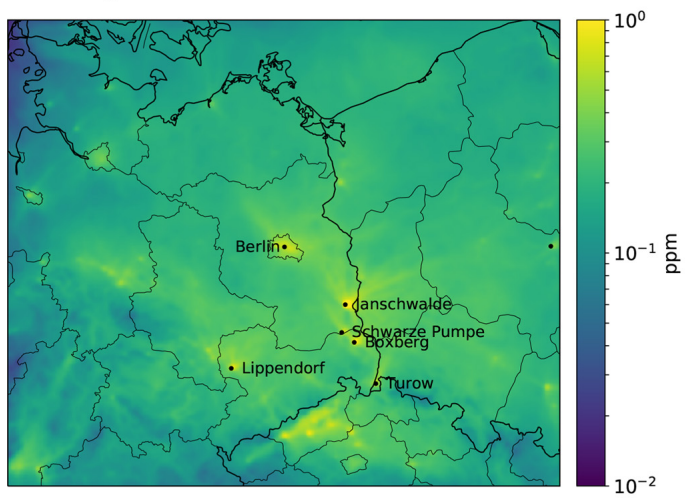

(c) $\mathrm{CO}_{2}$-VERT in July

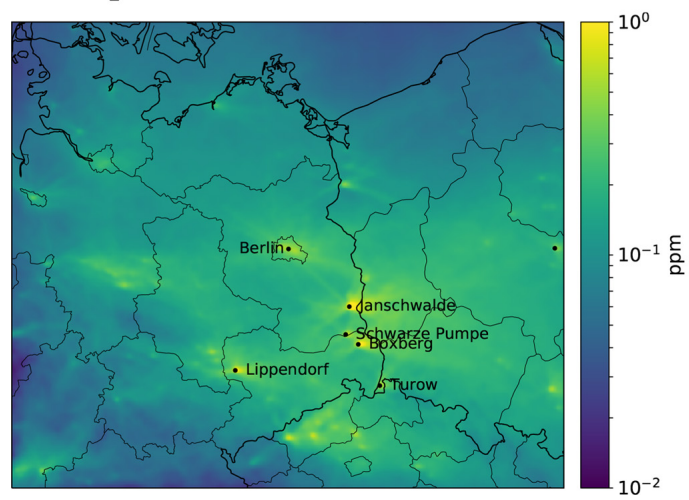

(b) $\mathrm{CO}_{2}{ }_{-} \mathrm{SURF}$ in January

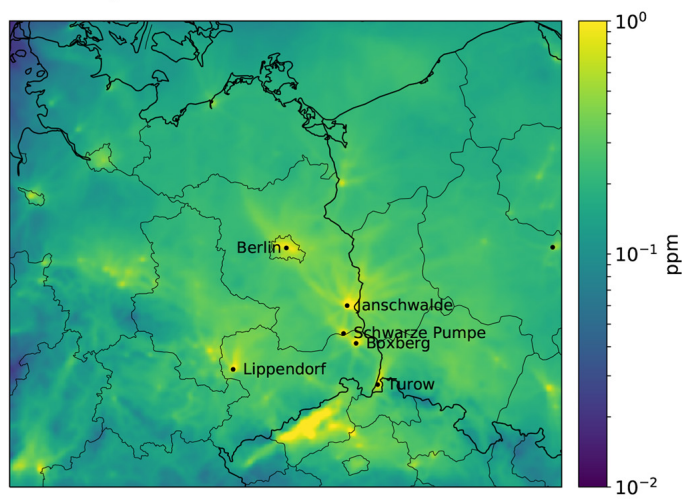

(d) $\mathrm{CO}_{2}{ }_{-} \mathrm{SURF}$ in July

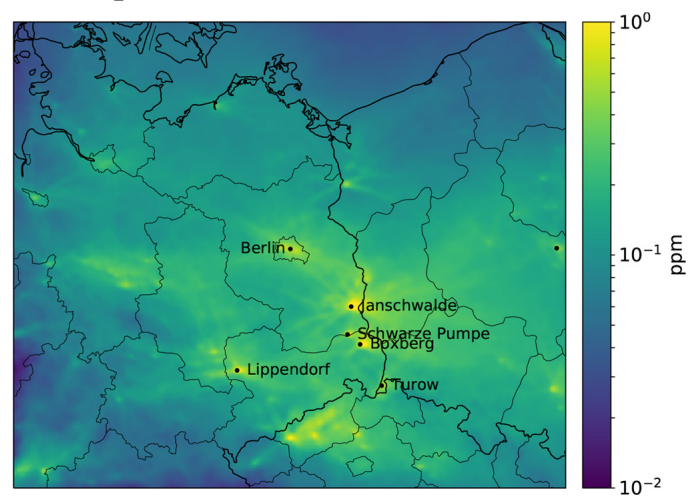

Figure 9. Column-averaged dry air mole fractions $\left(\mathrm{XCO}_{2}\right)$ at 11:30 LT in (a, b) January and (c, d) July contributed by all anthropogenic sources in the domain. $(\mathbf{a}, \mathbf{c})$ Tracer CO2_VERT released according to realistic vertical profiles. (b, c) Tracer CO2_SURF released only at the surface.

(a) January

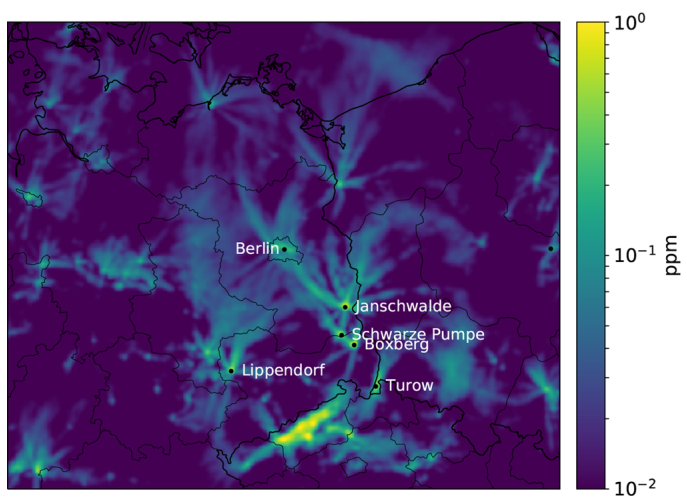

(b) July

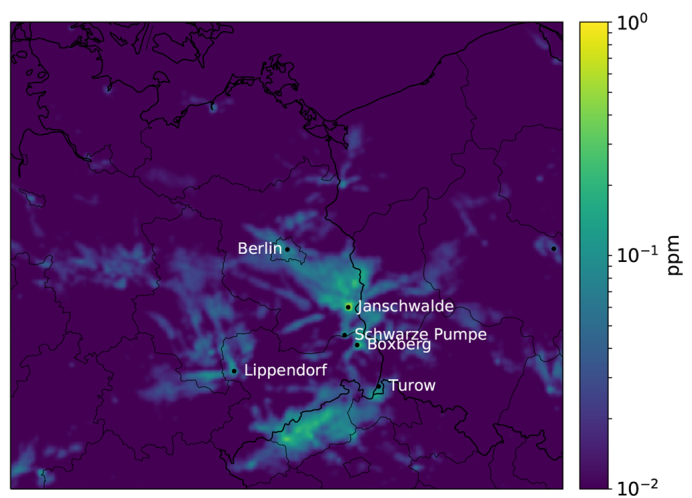

Figure 10. Difference in 11:30 LT column-averaged dry air mole fractions $\left(\mathrm{XCO}_{2}\right)$ between tracers CO2_SURF and CO2_VERT in (a) January and (b) July.

\section{Discussion}

The results for near-surface concentrations revealed a strong sensitivity to the vertical placement of emissions, especially in winter. Similarly large sensitivities were reported for air pollution simulations. By conducting a set of five 1-year
European-scale model simulations differing only in the vertical allocation of emissions, Mailler et al. (2013) found that ground-based concentrations of $\mathrm{SO}_{2}$, an air pollutant primarily released by point sources, increased on average by about $70 \%$ when reducing all emission heights by a factor of 4 . The changes were less significant (about $15 \%$ ) for $\mathrm{NO}_{2}$ due 
Table 4. Statistics of near-surface $\mathrm{CO}_{2}$ and column-averaged dry air mole $\mathrm{XCO}_{2}$ fractions in the model domain for the tracers CO2_VERT and CO2_SURF. Differences are presented in terms of (CO2_SURF-CO2_VERT)/CO2_VERT.

\begin{tabular}{lllrrrrr}
\hline Tracer & Month & Hour & $\begin{array}{r}\text { Mean } \\
(\mathrm{ppm})\end{array}$ & $\begin{array}{r}\text { Median } \\
(\mathrm{ppm})\end{array}$ & $\begin{array}{r}25 \% \\
(\mathrm{ppm})\end{array}$ & $\begin{array}{r}75 \% \\
(\mathrm{ppm})\end{array}$ & $\begin{array}{r}95 \% \\
(\mathrm{ppm})\end{array}$ \\
\hline CO2_VERT & January & $14: 00-16: 00 \mathrm{LT}$ & 3.34 & 3.13 & 2.35 & 4.00 & 5.76 \\
CO2_SURF & January & $14: 00-16: 00 \mathrm{LT}$ & 4.78 & 3.91 & 2.76 & 5.36 & 9.40 \\
Difference & & & $43 \%$ & $25 \%$ & $17 \%$ & $34 \%$ & $63 \%$ \\
CO2_VERT & \multirow{2}{*}{ July } & $14: 00-16: 00 \mathrm{LT}$ & 0.84 & 0.78 & 0.51 & 1.02 & 1.61 \\
CO2_SURF & July & $14: 00-16: 00 \mathrm{LT}$ & 0.96 & 0.80 & 0.54 & 1.09 & 1.81 \\
Difference & & & $14 \%$ & $3 \%$ & $6 \%$ & $7 \%$ & $12 \%$ \\
\hline XCO2_VERT & January & $11: 30 \mathrm{LT}$ & 0.193 & 0.185 & 0.145 & 0.230 & 0.317 \\
XCO2_SURF & January & $11: 30 \mathrm{LT}$ & 0.208 & 0.194 & 0.149 & 0.243 & 0.355 \\
Difference & & & $7.7 \%$ & $4.9 \%$ & $2.8 \%$ & $5.7 \%$ & $12.0 \%$ \\
XCO2_VERT & \multirow{2}{*}{ July } & $11: 30 \mathrm{LT}$ & 0.125 & 0.110 & 0.067 & 0.170 & 0.253 \\
XCO2_SURF & July & $11: 30 \mathrm{LT}$ & 0.131 & 0.112 & 0.068 & 0.173 & 0.276 \\
Difference & & & $4.8 \%$ & $1.8 \%$ & $1.5 \%$ & $1.8 \%$ & $9.1 \%$ \\
\hline
\end{tabular}

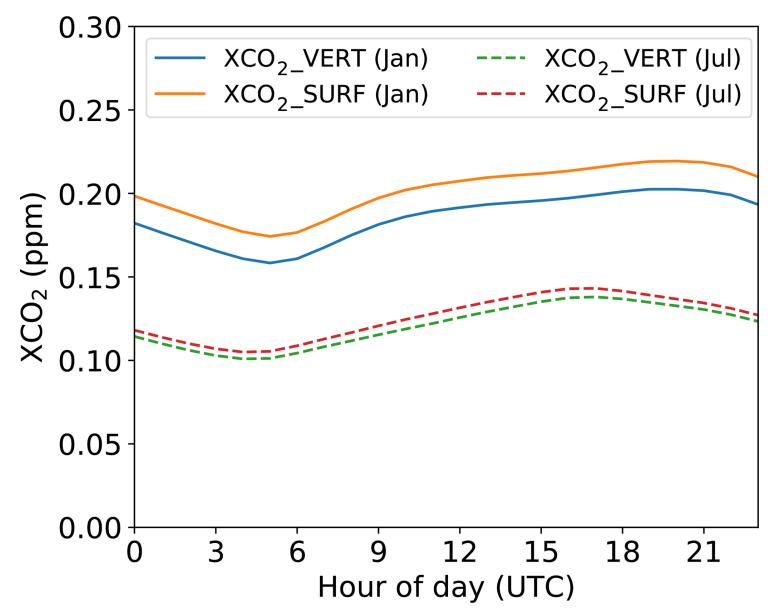

Figure 11. Mean diurnal cycles of column-averaged dry air mole fractions $\left(\mathrm{XCO}_{2}\right)$ of the tracers $\mathrm{CO} 2 \_$VERT and CO2_SURF in January and July.

to the larger contribution from traffic emissions. Sensitivities of a similar magnitude were reported by Guevara et al. (2014) for simulations over Spain when replacing the EMEP profiles for power plants by more realistic plume rise calculations.

The results of the present study may be considered as upper limits of the sensitivity for two reasons. First of all, our simulations covered a region in Europe with a particularly high density of coal-fired power plants. Simulations over other regions such as France, where electricity is mostly produced by nuclear power, would likely have yielded lower sensitivities. Nevertheless, averaged over Europe, large point sources are responsible for at least half of all anthropogenic $\mathrm{CO}_{2}$ emissions (52\% in 2011) according to the TNO/MACC-3 inventory, which underscores the general importance of properly allocating their emissions vertically.
Second, for most point sources in our domain, the standard EMEP profiles were applied, which tend to place emissions too high in the atmosphere as suggested consistently by Bieser et al. (2011); Guevara et al. (2014); Mailler et al. (2013) and by our own comparison with explicit plume rise simulations. Several improvements were already implemented in the present study, each of them leading to a reduction of the effective emission heights and likely to a more realistic representation as compared to EMEP. This included a modification of SNAP 9 profiles, the distinction between point and area sources, and the explicit computation of plume rise for the largest sources in the domain. Due to a lack of representative studies, these modifications were somewhat arbitrary. More studies like Bieser et al. (2011) and Pregger and Friedrich (2009) are needed, but should not only target large point sources but also emissions from the remaining $48 \%$ of emissions, including residential heating, even though their vertical placement will be less critical. Explicit plume rise computations for all large point sources as performed in some air quality models (Karamchandani et al., 2014) would be the best alternative to using static profiles, but this adds significant complexity to the model, and individual stack and flue gas parameters are not publicly available in Europe (Pregger and Friedrich, 2009).

None of the studies mentioned above considered the issue of interaction between multiple plumes and latent heat release in cooling tower plumes, which tend to enhance plume rise. The SNAP 1 profiles recommended by Bieser et al. (2011) and the simulations conducted here are only representative of isolated stacks, which is not consistent with any of the German coal-fired power plants in our domain. Comprehensive models for plume rise from single and multiple interacting cooling tower plumes have been presented by Schatzmann and Policastro (1984) and Policastro et al. (1994), but they seem not to be widely applied, although the code of 
(a)

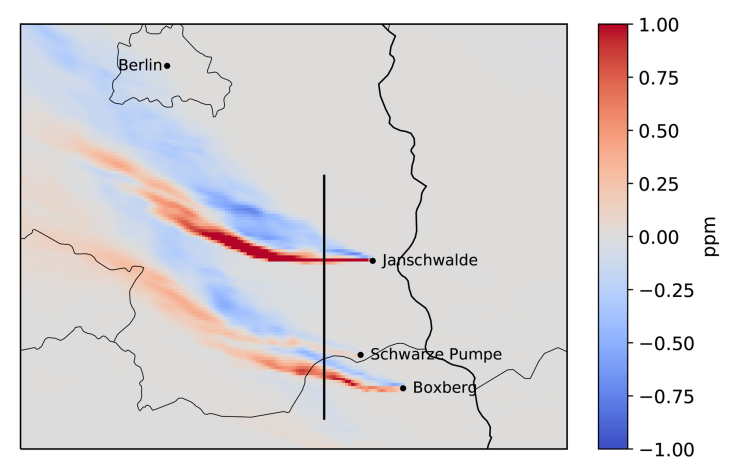

(b)

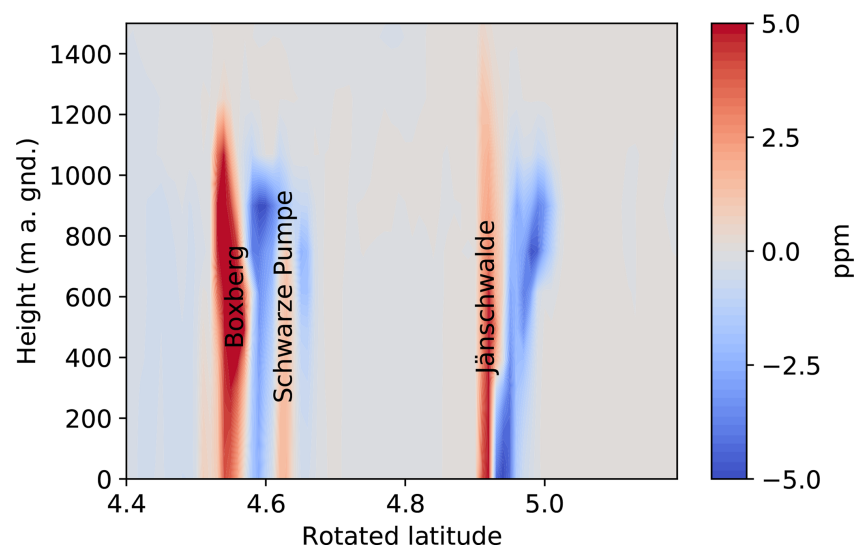

Figure 12. Difference on 2 July 2015 11:00 LT between power plant $\mathrm{CO}_{2}$ tracer with explicit plume rise (CO2_PP-PR) and released according to standard EMEP SNAP 1 profile (CO2_PP-EMEP). (a) Map of the difference in column-averaged dry air mole $\mathrm{XCO}_{2}$ fractions. (b) Vertical cross-section of the difference in $\mathrm{CO}_{2}$ along the transect indicated in panel (a). The length of this cross-section is about $100 \mathrm{~km}$.

Schatzmann and Policastro (1984) is available through the Association of German Engineers (VDI; https://www.vdi. de/index.php?id=4791, last access: 26 March 2019). Most plume rise studies date back 20 to 50 years, and modern computational fluid dynamics simulations are lacking, with the exception of the study of Bornoff and MokhtarzadehDehghan (2001) on the interaction of plumes from two adjacent cooling towers.

Mean afternoon differences at the surface in January between the tracers CO2_VERT and CO2_SURF are of the order of $1.5 \mathrm{ppm}$, which is close to $50 \%$ of the total anthropogenic $\mathrm{CO}_{2}$ signal due to emissions within the model domain. In summer, the relative differences in the afternoon are much smaller due to more efficient vertical mixing but still as large as $14 \%$. Inaccurate vertical placement of the emissions may thus lead to biases of a magnitude comparable to other error sources reported in the literature. Random uncertainties around $30 \%-50 \%$ of the regional biospheric $\mathrm{CO}_{2}$ signal have been estimated, for example, for model errors in PBL mixing (Gerbig et al., 2008) and in wind speed and direction (Lin and Gerbig, 2005). Systematic biases in simulated near-surface wind speeds of mesoscale weather prediction models like COSMO or WRF are typically on the order of $0.5-1 \mathrm{~m} \mathrm{~s}^{-1}$ or about $10 \%-20 \%$ of the mean wind speeds (Jiménez and Dudhia, 2012; Brunner et al., 2015; Bagley et al., 2018), which may translate into similar biases in nearsurface concentrations. Systematic differences in emission estimates using different regional transport and inverse modeling systems were reported to be around $20 \%-40 \%$ (Hu et al., 2014; Bergamaschi et al., 2018b). Our analysis focused on the situation in the lowest model layer at $0-20 \mathrm{~m}$. However, the recommended strategy for $\mathrm{CO}_{2}$ monitoring is to sample from tall towers well above the surface. At higher elevations, the model sensitivity to the vertical placement of emissions is likely smaller, which is another benefit of tall tower measurements in addition to their greater spatial representativeness.

Mean differences in total column $\mathrm{XCO}_{2}$ between the tracers $\mathrm{CO} 2$ _VERT and $\mathrm{CO} 2$ _SURF are much smaller, around $8 \%$ in winter and $5 \%$ in summer. However, differences are larger at the highest percentiles (about $10 \%$ at the $95 \%$ percentile), which are more relevant for satellite missions like Sentinel- $\mathrm{CO}_{2}$ designed to image individual plumes. Furthermore, the vertical placement of emissions has a significant effect on the speed and direction of individual plumes, suggesting that an accurate vertical placement is a critical requirement for inverse modeling of power plant emissions from satellite observations. Irrespective of a correct vertical placement of emissions, an appropriate simulation of power plant plumes will remain a great challenge for any mesoscale atmospheric transport model. Current approaches for estimating power plant emissions are circumventing this problem by directly matching the "observed" wind direction defined by the location of the plume, e.g., by fitting a Gaussian plume model (Krings et al., 2018; Nassar et al., 2017). However, these methods also need to make a realistic assumption about the height of the plume, since the mean advection speed of the plume needs to be estimated from a simulated or observed vertical wind profile.

\section{Conclusions}

We investigated the sensitivity of model-simulated nearsurface and total column $\mathrm{CO}_{2}$ concentrations to a realistic vertical allocation of anthropogenic emissions as opposed to the traditional approach of emitting $\mathrm{CO}_{2}$ only at the surface. The study was conducted using kilometer-scale atmospheric transport simulations for the year 2015 for a domain covering the city of Berlin and numerous power plants in Germany, Poland and Czech Republic. More than $50 \%$ of $\mathrm{CO}_{2}$ in Europe is emitted from large point sources, mostly through stacks and cooling towers, suggesting that a proper represen- 
tation of these sources in the vertical dimension may be critical. Our results indeed confirm a strong sensitivity of nearsurface afternoon concentrations: a regional $\mathrm{CO}_{2}$ tracer released in the model domain only at the surface was on average $43 \%$ higher in winter and $14 \%$ higher in summer than a tracer released according to realistic vertical profiles. Since measurements of $\mathrm{CO}_{2}$ are often taken from towers some 100 to $300 \mathrm{~m}$ above the surface (Bakwin et al., 1995), the impact on actual ground-based observations will likely be somewhat smaller.

Differences were smaller but not negligible (5\%-8\%) for total column $\mathrm{XCO}_{2}$, suggesting that the assimilation of satellite observations is less sensitive to the vertical placement of emissions than the assimilation of ground-based observations. Individual plumes as imaged by future $\mathrm{CO}_{2}$ satellites, however, may propagate more rapidly and in different directions when using realistic vertical profiles instead of releasing $\mathrm{CO}_{2}$ only at the surface.

Plume rise was explicitly simulated for the six largest power plants in the domain and for the 22 largest point sources in Berlin. Power plant plumes typically rose between 100 and $400 \mathrm{~m}$ above the top of the stacks. Plume rise showed significant seasonal and diurnal variability that would be missed when applying static vertical profiles. Simulated plume rise was on average more than $100 \mathrm{~m}$ lower than suggested by the frequently used EMEP profile for power plant emissions. An accurate vertical placement of emissions is not only critical for power plants but may also be relevant for the simulation of city plumes. In the case of Berlin, for example, more than $35 \%$ of $\mathrm{CO}_{2}$ is released through stacks presumably more than $90 \mathrm{~m}$ above surface.

We strongly recommend the representation of $\mathrm{CO}_{2}$ emissions in all three dimensions in regional atmospheric transport and inverse modeling studies. The specific impact on the model results will depend on factors such as vertical model resolution and boundary layer scheme but in general cannot be expected to be negligible. Current gridded emission inventories only provide information in two dimensions. Information on the source-specific vertical allocation of emissions as used in this study, conversely, is still sparse and should receive more attention in the future.

Data availability. Column-averaged dry air mole fractions of all simulated tracers are available both as 2-D fields and as synthetic level 2 satellite products through ESA. The total three-dimensional model output amounts to $7.5 \mathrm{~TB}$ and is archived at Empa servers. Selected fields or time periods can be made available upon request. The TNO/MACC-3 inventory is available through Copernicus (http://drdsi.jrc.ec.europa.eu/ dataset/tno-macc-iii-european-anthropogenic-emissions, last access: 26 March 2019). The emissions inventory of Berlin was kindly provided by Andreas Kerschbaumer (Senatsverwaltung Berlin) and is available for research upon request. The global $\mathrm{CO}_{2}$ simulation, which provided the lateral boundary conditions, was conducted in the framework of Copernicus Atmosphere Monitoring Service and can be retrieved from ECMWF's archive as experiment gf39, stream lwda, class rd.

Author contributions. DB led the project SMARTCARB, developed the idea of the present study and wrote the manuscript with input from all co-authors. GK designed the model experiments, conducted all simulations and contributed several figures. JM contributed the VPRM flux data required for the simulations. VC ported the COSMO-GHG extension to GPUs. OF surveyed and supported the porting to GPUs and the setup of the model on the supercomputer at CSCS. GB followed the project as external advisor and contributed critical input to an earlier version of the manuscript. YM and AL accompanied the study as ESA project and technical officers, respectively, and provided critical input and reviews during all phases of the project.

Competing interests. The authors declare that they have no conflict of interest.

Acknowledgements. This study was conducted in the context of the project SMARTCARB funded by the European Space Agency (ESA) under contract no. 4000119599/16/NL/FF/mg. The views expressed here can in no way be taken to reflect the official opinion of ESA. The work was supported by a grant from the Swiss National Supercomputing Centre (CSCS) under project ID d73. We acknowledge CSCS, the Swiss Federal Office for Meteorology and Climatology (MeteoSwiss) and ETH Zurich for their contributions to the development of the GPU-accelerated version of COSMO. We would like to thank Richard Engelen and Anna Agusti-Panareda (ECMWF) for providing support and access to global $\mathrm{CO}_{2}$ model simulation fields which were generated using the Copernicus Atmosphere Monitoring Service Information (2017). The TNO/MACC3 emissions inventory and temporal emission profiles were kindly provided by Hugo Denier van der Gon (TNO, the Netherlands). Finally, we are very grateful to Andreas Kerschbaumer (Senatsverwaltung Berlin) for providing the emission inventory of Berlin and additional material and for being available for discussions on its proper usage.

Review statement. This paper was edited by Michael Pitts and reviewed by three anonymous referees.

\section{References}

Achtemeier, G. L., Goodrick, S. A., Liu, Y., Garcia-Menendez, F., Hu, Y., and Odman, M. T.: Modeling Smoke PlumeRise and Dispersion from Southern United States Prescribed Burns with Daysmoke, Atmosphere, 2, 358-388, https://doi.org/10.3390/atmos2030358, 2011.

Agustí-Panareda, A., Massart, S., Chevallier, F., Boussetta, S., Balsamo, G., Beljaars, A., Ciais, P., Deutscher, N. M., Engelen, R., Jones, L., Kivi, R., Paris, J.-D., Peuch, V.-H., Sherlock, V., Vermeulen, A. T., Wennberg, P. O., and Wunch, D.: Forecast- 
ing global atmospheric $\mathrm{CO}_{2}$, Atmos. Chem. Phys., 14, 1195911983, https://doi.org/10.5194/acp-14-11959-2014, 2014.

Amt für Statistik Berlin-Brandenburg: Statistischer Bericht, Energie- und $\mathrm{CO}_{2}$-Bilanz in Berlin 2015, Tech. rep., Potsdam, Germany, available at: http://www.statistik-berlin-brandenburg. de (last access: 26 March 2019), 2018.

Andrews, A. E., Kofler, J. D., Trudeau, M. E., Williams, J. C., Neff, D. H., Masarie, K. A., Chao, D. Y., Kitzis, D. R., Novelli, P. C., Zhao, C. L., Dlugokencky, E. J., Lang, P. M., Crotwell, M. J., Fischer, M. L., Parker, M. J., Lee, J. T., Baumann, D. D., Desai, A. R., Stanier, C. O., De Wekker, S. F. J., Wolfe, D. E., Munger, J. W., and Tans, P. P.: $\mathrm{CO}_{2}, \mathrm{CO}$, and $\mathrm{CH}_{4}$ measurements from tall towers in the NOAA Earth System Research Laboratory's Global Greenhouse Gas Reference Network: instrumentation, uncertainty analysis, and recommendations for future high-accuracy greenhouse gas monitoring efforts, Atmos. Meas. Tech., 7, 647687, https://doi.org/10.5194/amt-7-647-2014, 2014.

Bagley, J. E., Jeong, S., Cui, X., Newman, S., Zhang, J., Priest, C., Campos-Pineda, M., Andrews, A. E., Bianco, L., Lloyd, M., Lareau, N., Clements, C., and Fischer, M. L.: Assessment of an atmospheric transport model for annual inverse estimates of California greenhouse gas emissions, J. Geophys. Res.-Atmos., 122, 1901-1918, https://doi.org/10.1002/2016JD025361, 2018.

Bakwin, P. S., Tans, P. P., Zhao, C., Ussler, W., and Quesnell, E.: Measurements of carbon dioxide on a very tall tower, Tellus B, 47, 535-549, 1995.

Baldauf, M., Seifert, A., Förstner, J., Majewski, D., Raschendorfer, M., and Reinhardt, T.: Operational Convective-Scale Numerical Weather Prediction with the COSMO Model: Description and Sensitivities, Mon. Weather Rev., 139, 3887-3905, https://doi.org/10.1175/MWR-D-10-05013.1, 2011.

Bergamaschi, P., Danila, A., Weiss, R., Ciais, P., Thompson, R., Brunner, D., Levin, I., Meijer, Y., Chevallier, F., JanssensMaenhout, G., Bovensmann, H., Crisp, D., Basu, S., Dlugokencky, E., Engelen, R., Gerbig, C., Günther, D., Hammer, S., Henne, S., Houweling, S., Karstens, U., Kort, E., Maione, M., Manning, A., Miller, J., Montzka, S., Pandey, S., Peters, W., Peylin, P., Pinty, B., Ramonet, M., Reimann, S., Röckmann, T., Schmidt, M., Strogies, M., Sussams, J., Tarasova, O., van Aardenne, J., Vermeulen, A., and Vogel, F.: Atmospheric monitoring and inverse modelling for verification of greenhouse gas inventories, no. EUR $29276 \mathrm{EN}$ in JRC Science for policy report, Publications Office of the European Union, Luxembourg, https://doi.org/10.2760/759928, 2018a.

Bergamaschi, P., Karstens, U., Manning, A. J., Saunois, M., Tsuruta, A., Berchet, A., Vermeulen, A. T., Arnold, T., JanssensMaenhout, G., Hammer, S., Levin, I., Schmidt, M., Ramonet, M., Lopez, M., Lavric, J., Aalto, T., Chen, H., Feist, D. G., Gerbig, C., Haszpra, L., Hermansen, O., Manca, G., Moncrieff, J., Meinhardt, F., Necki, J., Galkowski, M., O'Doherty, S., Paramonova, N., Scheeren, H. A., Steinbacher, M., and Dlugokencky, E.: Inverse modelling of European $\mathrm{CH}_{4}$ emissions during 2006-2012 using different inverse models and reassessed atmospheric observations, Atmos. Chem. Phys., 18, 901-920, https://doi.org/10.5194/acp-18-901-2018, 2018b.

Bieser, J., Aulinger, A., Matthias, V., Quante, M., and van der Gon, H. D.: Vertical emission profiles for Europe based on plume rise calculations, Environ. Pollut., 159, 2935-2946, https://doi.org/10.1016/j.envpol.2011.04.030, 2011.
Bornoff, R. and Mokhtarzadeh-Dehghan, M.: A numerical study of interacting buoyant cooling-tower plumes, Atmos. Environ., 35, 589-598, https://doi.org/10.1016/S1352-2310(00)00296-X, 2001.

Bousquet, P., Peylin, P., Ciais, P., Le Quéré, C., Friedlingstein, P., and Tans, P. P.: Regional changes in carbon dioxide fluxes of land and oceans since 1980, Science, 290, 1342-1347, 2000.

Bovensmann, H., Buchwitz, M., Burrows, J. P., Reuter, M., Krings, T., Gerilowski, K., Schneising, O., Heymann, J., Tretner, A., and Erzinger, J.: A remote sensing technique for global monitoring of power plant $\mathrm{CO}_{2}$ emissions from space and related applications, Atmos. Meas. Tech., 3, 781-811, https://doi.org/10.5194/amt-3781-2010, 2010.

Briggs, G. A.: Plume rise and buoyancy effects, atmospheric sciences and power production, vol. DOE/TIC27601 (DE84005177), p. 850, TN Technical Information Center, U.S. Dept. of Energy, Oak Ridge, USA, https://doi.org/10.2172/6503687, 1984.

Broquet, G., Chevallier, F., Rayner, P., Aulagnier, C., Pison, I., Ramonet, M., Schmidt, M., Vermeulen, A. T., and Ciais, P.: A European summertime $\mathrm{CO}_{2}$ biogenic flux inversion at mesoscale from continuous in situ mixing ratio measurements, J. Geophys. Res.Atmos., 116, D23303, https://doi.org/10.1029/2011JD016202, 2011.

Broquet, G., Bréon, F.-M., Renault, E., Buchwitz, M., Reuter, M., Bovensmann, H., Chevallier, F., Wu, L., and Ciais, P.: The potential of satellite spectro-imagery for monitoring $\mathrm{CO}_{2}$ emissions from large cities, Atmos. Meas. Tech., 11, 681-708, https://doi.org/10.5194/amt-11-681-2018, 2018.

Brunner, D., Savage, N., Jorba, O., Eder, B., Giordano, L., Badia, A., Balzarini, A., Baró, R., Bianconi, R., Chemel, C., Curci, G., Forkel, R., Jiménez-Guerrero, P., Hirtl, M., Hodzic, A., Honzak, L., Im, U., Knote, C., Makar, P., Manders-Groot, A., van Meijgaard, E., Neal, L., Pérez, J. L., Pirovano, G., Jose, R. S., Schöder, W., Sokhi, R. S., Syrakov, D., Torian, A., Tuccella, P., Werhahn, J., Wolke, R., Yahya, K., Zabkar, R., Zhang, Y., Hogrefe, C., and Galmarini, S.: Comparative analysis of meteorological performance of coupled chemistry-meteorology models in the context of AQMEII phase 2, Atmos. Environ., 115, 470-498, https://doi.org/10.1016/j.atmosenv.2014.12.032, 2015.

Builtjes, P., van Loon, M., Schaap, M., Teeuwisse, S., Visschedijk, A., and Bloos, J.: Project on the modelling and verification of ozone reduction strategies: contribution of TNO-MEP, Tech. Rep. TNO-report MEP-R2003/166, TNO, Netherlands Organisation for applied scientific research, Apeldoorn, the Netherlands, 2003.

Busch, D., Harte, R., Krätzig, W. B., and Montag, U.: New natural draft cooling tower of $200 \mathrm{~m}$ of height, Eng. Struct., 24, 15091521, https://doi.org/10.1016/S0141-0296(02)00082-2, 2002.

Chan, D., Ishizawa, M., Higuchi, K., Maksyutov, S., and Chen, J.: Seasonal $\mathrm{CO}_{2}$ rectifier effect and large-scale extratropical atmospheric transport, J. Geophys. Res.-Atmos., 113, D17309, https://doi.org/10.1029/2007JD009443, 2008.

Chevallier, F., Ciais, P., Conway, T. J., Aalto, T., Anderson, B. E., Bousquet, P., Brunke, E. G., Ciattaglia, L., Esaki, Y., Fröhlich, M., Gomez, A., Gomez-Pelaez, A. J., Haszpra, L., Krummel, P. B., Langenfelds, R. L., Leuenberger, M., Machida, T., Maignan, F., Matsueda, H., Morguí, J. A., Mukai, H., Nakazawa, T., Peylin, P., Ramonet, M., Rivier, L., Sawa, Y., 
Schmidt, M., Steele, L. P., Vay, S. A., Vermeulen, A. T., Wofsy, S., and Worthy, D.: $\mathrm{CO}_{2}$ surface fluxes at grid point scale estimated from a global 21 year reanalysis of atmospheric measurements, J. Geophys. Res., 115, D21307, https://doi.org/10.1029/2010JD013887, 2010.

Ciais, P., Dolman, A. J., Bombelli, A., Duren, R., Peregon, A., Rayner, P. J., Miller, C., Gobron, N., Kinderman, G., Marland, G., Gruber, N., Chevallier, F., Andres, R. J., Balsamo, G., Bopp, L., Bréon, F.-M., Broquet, G., Dargaville, R., Battin, T. J., Borges, A., Bovensmann, H., Buchwitz, M., Butler, J., Canadell, J. G., Cook, R. B., DeFries, R., Engelen, R., Gurney, K. R., Heinze, C., Heimann, M., Held, A., Henry, M., Law, B., Luyssaert, S., Miller, J., Moriyama, T., Moulin, C., Myneni, R. B., Nussli, C., Obersteiner, M., Ojima, D., Pan, Y., Paris, J.-D., Piao, S. L., Poulter, B., Plummer, S., Quegan, S., Raymond, P., Reichstein, M., Rivier, L., Sabine, C., Schimel, D., Tarasova, O., Valentini, R., Wang, R., van der Werf, G., Wickland, D., Williams, M., and Zehner, C.: Current systematic carbon-cycle observations and the need for implementing a policy-relevant carbon observing system, Biogeosciences, 11, 3547-3602, https://doi.org/10.5194/bg-11-3547-2014, 2014.

Ciais, P., Denier Van der Gon, H., Engelen, R., Heimann, M., Janssens-Maenhout, G., Rayner, P., and Scholze, M.: Towards a European Operational Observing System to Monitor Fossil $\mathrm{CO}_{2}$ emissions, Tech. rep., European Commission, B-1049 Brussels, https://doi.org/10.2788/350433, 2015.

Davin, E. L., Stöckli, R., Jaeger, E. B., Levis, S., and Seneviratne, S. I.: COSMO-CLM2: a new version of the COSMOCLM model coupled to the Community Land Model, Clim. Dynam., 37, 1889-1907, https://doi.org/10.1007/s00382-011-1019z, 2011.

European Environment Agency, EMEP/CORINAIR Emission Inventory Guidebook - 3rd edition 2001, Tech. Rep. 30/2001, Copenhagen, Denmark, available at: https: //www.eea.europa.eu/publications/technical_report_2001_3 (last access: 26 March 2019), 2002.

Fischer, M. L., Parazoo, N., Brophy, K., Cui, X., Jeong, S., Liu, J., Keeling, R., Taylor, T. E., Gurney, K., Oda, T., and Graven, H.: Simulating estimation of California fossil fuel and biosphere carbon dioxide exchanges combining in situ tower and satellite column observations, J. Geophys. Res.-Atmos., 122, 3653-3671, https://doi.org/10.1002/2016JD025617, 2018.

Fuhrer, O., Osuna, C., Lapillonne, X., Gysi, T., Cumming, B., Bianco, M., Arteaga, A., and Schulthess, T.: Towards a performance portable, architecture agnostic implementation strategy for weather and climate models, Supercomputing Frontiers and Innovations, 1, 44-61, available at: http://superfri.org/superfri/ article/view/17 (last access: 26 March 2019), 2014.

Ganshin, A., Oda, T., Saito, M., Maksyutov, S., Valsala, V., Andres, R. J., Fisher, R. E., Lowry, D., Lukyanov, A., Matsueda, H., Nisbet, E. G., Rigby, M., Sawa, Y., Toumi, R., Tsuboi, K., Varlagin, A., and Zhuravlev, R.: A global coupled Eulerian-Lagrangian model and $1 \times 1 \mathrm{~km} \mathrm{CO}_{2}$ surface flux dataset for high-resolution atmospheric CO2 transport simulations, Geosci. Model Dev., 5, 231-243, https://doi.org/10.5194/gmd-5-231-2012, 2012.

Gately, C. K. and Hutyra, L. R.: Large Uncertainties in Urban-Scale Carbon Emissions, J. Geophys. Res.-Atmos., 122, 11242-11260, https://doi.org/10.1002/2017JD027359, 2017.
Gerbig, C., Körner, S., and Lin, J. C.: Vertical mixing in atmospheric tracer transport models: error characterization and propagation, Atmos. Chem. Phys., 8, 591-602, https://doi.org/10.5194/acp-8-591-2008, 2008.

Goeckede, M., Michalak, A. M., Vickers, D., Turner, D. P., and Law, B. E.: Atmospheric inverse modeling to constrain regional-scale $\mathrm{CO}_{2}$ budgets at high spatial and temporal resolution, J. Geophys. Res., 115, 1-23, https://doi.org/10.1029/2009JD012257, 2010.

Graven, H., Fischer, M. L., Lueker, T., Jeong, S., Guilderson, T. P., Keeling, R. F., Bambha, R., Brophy, K., Callahan, W., Cui, X., Frankenberg, C., Gurney, K. R., LaFranchi, B. W., Lehman, S. J., Michelsen, H., Miller, J. B., Newman, S., Paplawsky, W., Parazoo, N. C., Sloop, C., and Walker, S. J.: Assessing fossil fuel $\mathrm{CO}_{2}$ emissions in California using atmospheric observations and models, Environ. Res. Lett., 13, 065007, https://doi.org/10.1088/1748-9326/aabd43, 2018.

Guevara, M., Soret, A., Arevalo, G., Martinez, F., and Baldasano, J. M.: Implementation of plume rise and its impacts on emissions and air quality modelling, Atmos. Environ., 99, 618-629, https://doi.org/10.1016/j.atmosenv.2014.10.029, 2014.

Hanna, S. R.: Rise and Condensation of Large Cooling Tower Plumes, J. Appl. Meteorol., 11, 793-799, 1972.

Hase, F., Frey, M., Blumenstock, T., Groß, J., Kiel, M., Kohlhepp, R., Mengistu Tsidu, G., Schäfer, K., Sha, M. K., and Orphal, J.: Application of portable FTIR spectrometers for detecting greenhouse gas emissions of the major city Berlin, Atmos. Meas. Tech., 8, 3059-3068, https://doi.org/10.5194/amt-8-3059-2015, 2015.

Hogue, S., Marland, E., Andres, R. J., Marland, G., and Woodard, D.: Uncertainty in gridded $\mathrm{CO}_{2}$ emissions estimates, Earth's Future, 4, 225-239, https://doi.org/10.1002/2015EF000343, 2016.

Houyoux, M., Vukovich, J., Seppanen, C., and Brandmeyer, J. E.: SMOKE User Manual, Tech. rep., MCNC Environmental Modeling Center, College Park, MD, USA, 2002.

Hu, L., Montzka, S. A., Miller, J. B., Andrews, A. E., Lehman, S. J., Miller, B. R., Thoning, K., Sweeney, C., Chen, H., Godwin, D. S., Masarie, K., Bruhwiler, L., Fischer, M. L., Biraud, S. C., Torn, M. S., Mountain, M., Nehrkorn, T., Eluszkiewicz, J., Miller, S., Draxler, R. R., Stein, A. F., Hall, B. D., Elkins, J. W., and Tans, P. P.: U.S. emissions of HFC-134a derived for 2008-2012 from an extensive flask-air sampling network, J. Geophys. Res.-Atmos., 120, 801-825, https://doi.org/10.1002/2014JD022617, 2014.

Jiménez, P. A. and Dudhia, J.: Improving the Representation of Resolved and Unresolved Topographic Effects on Surface Wind in the WRF Model, J. Appl. Meteorol. Clim., 51, 300-316, https://doi.org/10.1175/JAMC-D-11-084.1, 2012.

Jung, M., Henkel, K., Herold, M., and Churkina, G.: Exploiting synergies of global land cover products for carbon cycle modeling, Remote Sens. Environ., 101, 534-553, https://doi.org/10.1016/j.rse.2006.01.020, 2006.

Karamchandani, P., Johnson, J., Yarwood, G., and Knipping, E.: Implementation and application of sub-grid-scale plume treatment in the latest version of EPA's third-generation air quality model, CMAQ 5.01, J. Air Waste Manage., 64, 453-467, https://doi.org/10.1080/10962247.2013.855152, 2014.

Kent, J., Whitehead, J. P., Jablonowski, C., and Rood, R. B.: Determining the effective resolution of advection schemes. 
Part I: Dispersion analysis, J. Comput. Phys., 278, 485-496, https://doi.org/10.1016/j.jcp.2014.01.043, 2014.

Kountouris, P., Gerbig, C., Rödenbeck, C., Karstens, U., Koch, T. F., and Heimann, M.: Technical Note: Atmospheric $\mathrm{CO}_{2}$ inversions on the mesoscale using data-driven prior uncertainties: methodology and system evaluation, Atmos. Chem. Phys., 18, 30273045, https://doi.org/10.5194/acp-18-3027-2018, 2018.

Kretschmer, R., Gerbig, C., Karstens, U., and Koch, F.-T.: Error characterization of $\mathrm{CO}_{2}$ vertical mixing in the atmospheric transport model WRF-VPRM, Atmos. Chem. Phys., 12, 2441-2458, https://doi.org/10.5194/acp-12-2441-2012, 2012.

Kretschmer, R., Gerbig, C., Karstens, U., Biavati, G., Vermeulen, A., Vogel, F., Hammer, S., and Totsche, K. U.: Impact of optimized mixing heights on simulated regional atmospheric transport of $\mathrm{CO}_{2}$, Atmos. Chem. Phys., 14, 7149-7172, https://doi.org/10.5194/acp-14-7149-2014, 2014.

Krings, T., Neininger, B., Gerilowski, K., Krautwurst, S., Buchwitz, M., Burrows, J. P., Lindemann, C., Ruhtz, T., Schüttemeyer, D., and Bovensmann, H.: Airborne remote sensing and in situ measurements of atmospheric $\mathrm{CO}_{2}$ to quantify point source emissions, Atmos. Meas. Tech., 11, 721-739, https://doi.org/10.5194/amt-11-721-2018, 2018.

Kuenen, J. J. P., Visschedijk, A. J. H., Jozwicka, M., and Denier van der Gon, H. A. C.: TNO-MACC_II emission inventory; a multi-year (2003-2009) consistent high-resolution European emission inventory for air quality modelling, Atmos. Chem. Phys., 14, 10963-10976, https://doi.org/10.5194/acp-14-109632014, 2014.

Kuhlmann, G., Clément, V., Marschall, J., Fuhrer, O., Broquet, G., Schnadt-Poberaj, C., Löscher, A., Meijer, Y., and Brunner, D.: SMARTCARB - Use of Satellite Measurements of Auxiliary Reactive Trace Gases for Fossil Fuel Carbon Dioxide Emission Estimation, Final report of ESA study contract n ${ }^{\circ} 4000119599 / 16 / \mathrm{NL} / \mathrm{FF} / \mathrm{mg}$, Tech. rep., Empa, Swiss Federal Laboratories for Materials Science and Technology, Dübendorf, Switzerland, available at: https://www.empa.ch/documents/ 56101/617885/FR_Smartcarb_final_Jan2019.pdf (last access: 26 March 2019), 2019.

Lapillonne, X. and Fuhrer, O.: Using Compiler Directives to Port Large Scientific Applications to GPUs: An Example from Atmospheric Science, Parallel Processing Letters, 24, 1450003, https://doi.org/10.1142/S0129626414500030, 2014.

Lauvaux, T., Pannekoucke, O., Sarrat, C., Chevallier, F., Ciais, P., Noilhan, J., and Rayner, P. J.: Structure of the transport uncertainty in mesoscale inversions of $\mathrm{CO}_{2}$ sources and sinks using ensemble model simulations, Biogeosciences, 6, 1089-1102, https://doi.org/10.5194/bg-6-1089-2009, 2009.

Lauvaux, T., Miles, N. L., Deng, A., Richardson, S. J., Cambaliza, M. O., Davis, K. J., Gaudet, B., Gurney, K. R., Huang, J., O'Keefe, D., Song, Y., Karion, A., Oda, T., Patarasuk, R., Razlivanov, I., Sarmiento, D., Shepson, P., Sweeney, C., Turnbull, J., and $\mathrm{Wu}$, K.: High-resolution atmospheric inversion of urban $\mathrm{CO}_{2}$ emissions during the dormant season of the Indianapolis Flux Experiment (INFLUX), J. Geophys. Res.-Atmos., 121, 52135236, https://doi.org/10.1002/2015JD024473, 2016.

Leutwyler, D., Lüthi, D., Ban, N., Fuhrer, O., and Schär, C.: Evaluation of the convection-resolving climate modeling approach on continental scales, J. Geophys. Res.-Atmos., 122, 5237-5258, https://doi.org/10.1002/2016JD026013, 2017.
Lin, J. C. and Gerbig, C.: Accounting for the effect of transport errors on tracer inversions, Geophys. Res. Lett., 32, L01802, https://doi.org/10.1029/2004GL021127, 2005.

Lin, J. C., Gerbig, C., Wofsy, S. C., Andrews, A. E., Daube, B. C., Davis, K. J., and Grainger, C. A.: A near-field tool for simulating the upstream influence of atmospheric observations: The Stochastic Time-Inverted Lagrangian Transport (STILT) model, J. Geophys. Res.-Atmos., 108, 4493, https://doi.org/10.1029/2002JD003161, 2003.

Liu, Y., Gruber, N., and Brunner, D.: Spatiotemporal patterns of the fossil-fuel $\mathrm{CO}_{2}$ signal in central Europe: results from a high-resolution atmospheric transport model, Atmos. Chem. Phys., 17, 14145-14169, https://doi.org/10.5194/acp-17-141452017, 2017.

Mahadevan, P., Wofsy, S., Matross, D. M., Xiao, X., Dunn, A. L., Lin, J. C., Gerbig, C., Munger, J. W., Chow, V. Y., and Gottlieb, E. W.: A satellite-based biosphere parameterization for net ecosystem $\mathrm{CO}_{2}$ exchange: Vegetation Photosynthesis and Respiration Model (VPRM), Global Biogeochem. Cy., 22, 1-17, https://doi.org/10.1029/2006GB002735, 2008.

Mailler, S., Khvorostyanov, D., and Menut, L.: Impact of the vertical emission profiles on background gas-phase pollution simulated from the EMEP emissions over Europe, Atmos. Chem. Phys., 13, 5987-5998, https://doi.org/10.5194/acp-135987-2013, 2013.

Meesters, A. G. C. A., Tolk, L. F., Peters, W., Hutjes, R. W. A., Vellinga, O. S., Elbers, J. a., Vermeulen, A. T., van der Laan, S., Neubert, R. E. M., Meijer, H. A. J., and Dolman, A. J.: Inverse carbon dioxide flux estimates for the Netherlands, J. Geophys. Res.Atmos., 117, D20306, https://doi.org/10.1029/2012JD017797, 2012.

Nassar, R., Hill, T. G., McLinden, C. A., Wunch, D., Jones, D. B. A., and Crisp, D.: Quantifying $\mathrm{CO}_{2}$ Emissions From Individual Power Plants From Space, Geophys. Res. Lett., 44, 1004510053, https://doi.org/10.1002/2017GL074702, 2017.

Nisbet, E. and Weiss, R.: Top-down versus bottom-up, Science, 328, 1241-1243, https://doi.org/10.1126/science.1189936, 2010.

Oney, B., Henne, S., Gruber, N., Leuenberger, M., Bamberger, I., Eugster, W., and Brunner, D.: The CarboCount $\mathrm{CH}$ sites: characterization of a dense greenhouse gas observation network, Atmos. Chem. Phys., 15, 11147-11164, https://doi.org/10.5194/acp-15-11147-2015, 2015.

Peters, W., Krol, M. C., van der Werf, G. R., Houweling, S., Jones, C. D., Hughes, J., Schaefer, K., Masarie, K. A., Jacobson, A. R., Miller, J. B., Cho, C. H., Ramonet, M., Schmidt, M., Ciattaglia, L., Apadula, F., Heltai, D., Meinhardt, F., Di Sarra, A. G., Piacentino, S., Sferlazzo, D., Aalto, T., Hatakka, J., Ström, J., Haszpra, L., Meijer, H. A. J., Van Der Laan, S., Neubert, R. E. M., Jordan, A., Rodó, X., Morguí, J.-A., Vermeulen, A. T., Popa, E., Rozanski, K., Zimnoch, M., Manning, A. C., Leuenberger, M., Uglietti, C., Dolman, A. J., Ciais, P., Heimann, M., and Tans, P. P.: Seven years of recent European net terrestrial carbon dioxide exchange constrained by atmospheric observations, Glob. Change Biol., 16, 1317-1337, https://doi.org/10.1111/j.1365-2486.2009.02078.x, 2010.

Peylin, P., Law, R. M., Gurney, K. R., Chevallier, F., Jacobson, A. R., Maki, T., Niwa, Y., Patra, P. K., Peters, W., Rayner, P. J., Rödenbeck, C., van der Laan-Luijkx, I. T., and Zhang, X.: Global atmospheric carbon budget: results from an ensemble of 
atmospheric $\mathrm{CO}_{2}$ inversions, Biogeosciences, 10, 6699-6720, https://doi.org/10.5194/bg-10-6699-2013, 2013.

Pillai, D., Buchwitz, M., Gerbig, C., Koch, T., Reuter, M., Bovensmann, H., Marshall, J., and Burrows, J. P.: Tracking city $\mathrm{CO}_{2}$ emissions from space using a high-resolution inverse modelling approach: a case study for Berlin, Germany, Atmos. Chem. Phys., 16, 9591-9610, https://doi.org/10.5194/acp-169591-2016, 2016.

Pinty, B., Janssens-Maenhout, G., Dowell, M., Zunker, H., Brunhes, T., Ciais, P., Dee, D., Denier van der Gon, H., Dolman, H., Drinkwater, M., Engelen, R., Heimann, M., Holmlund, K., Husband, R., Kentarchos, A., Meijer, Y., Palmer, P., and Scholze, M.: An Operational Anthropogenic $\mathrm{CO}_{2}$ Emissions Monitoring \& Verification Support capacity - Baseline Requirements, Model Component and Functional Architecture, Tech. Rep. EUR 28736 EN, European Commission, B-1049 Brussels, https://doi.org/10.2760/08644, 2017.

Policastro, A., Dunn, W., and Carhart, R.: A model for seasonal and annual cooling tower impacts, Atmos. Environ., 28, 379395, https://doi.org/10.1016/1352-2310(94)90118-X, 1994.

Pregger, T. and Friedrich, R.: Effective pollutant emission heights for atmospheric transport modelling based on real-world information, Environ. Pollut., 157, 552-560, https://doi.org/10.1016/j.envpol.2008.09.027, 2009.

Roches, A. and Fuhrer, O.: Tracer module in the COSMO model, Tech. Rep. 20, Consortium for Small-Scale Modelling (COSMO), Center for Climate Systems Modelling (C2SM) and MeteoSwiss, Switzerland, available at: http://www.cosmo-model.org/content/model/documentation/ techReports/default.htm (last access: 26 March 2019), 2012.

Rockel, B., Will, A., and Hense, A.: The Regional Climate Model COSMO-CLM (CCLM), Meteorol. Z., 17, 347-348, https://doi.org/10.1127/0941-2948/2008/0309, 2008.

Rödenbeck, C., Zaehle, S., Keeling, R., and Heimann, M.: How does the terrestrial carbon exchange respond to interannual climatic variations? A quantification based on atmospheric $\mathrm{CO}_{2}$ data, Biogeosciences, 15, 2481-2498, https://doi.org/10.5194/bg-15-2481-2018, 2018.

Sarrat, C., Noilhan, J., Lacarrére, P., Ceschia, E., Ciais, P., Dolman, A. J., Elbers, J. A., Gerbig, C., Gioli, B., Lauvaux, T., Miglietta, F., Neininger, B., Ramonet, M., Vellinga, O., and Bonnefond, J. M.: Mesoscale modelling of the $\mathrm{CO}_{2}$ interactions between the surface and the atmosphere applied to the April 2007 CERES field experiment, Biogeosciences, 6, 633646, https://doi.org/10.5194/bg-6-633-2009, 2009.

Schatzmann, M. and Policastro, A. J.: An advanced integral model for cooling tower plume dispersion, Atmos. Environ., 18, 663674, https://doi.org/10.1016/0004-6981(84)90253-1, 1984.
Stohl, A., Forster, C., Frank, A., Seibert, P., and Wotawa, G.: Technical note: The Lagrangian particle dispersion model FLEXPART version 6.2, Atmos. Chem. Phys., 5, 2461-2474, https://doi.org/10.5194/acp-5-2461-2005, 2005.

Timmermans, R., van der Gon, H. D., Kuenen, J., Segers, A., Honoré, C., Perrussel, O., Builtjes, P., and Schaap, M.: Quantification of the urban air pollution increment and its dependency on the use of down-scaled and bottomup city emission inventories, Urban Climate, 6, 44-62, https://doi.org/10.1016/j.uclim.2013.10.004, 2013.

Uebel, M. and Bott, A.: Influence of complex terrain and anthropogenic emissions on atmospheric $\mathrm{CO}_{2}$ patterns - a highresolution numerical analysis, Q. J. Roy. Meteor. Soc., 144, 34 47, https://doi.org/10.1002/qj.3182, 2018.

United Nations Framework Convention on Climate Change: Report of the Conference of the Parties on its twenty-first session, held in Paris from 30 November to 13 December 2015. Addendum. Part two: Action taken by the Conference of the Parties at its twenty-first session, Tech. Rep. FCCC/CP/2015/10/Add.1, United Nations, Geneva, Switzerland, available at: http://unfccc.int/documentation/documents/ advanced_search/items/6911.php?priref=600008865 (last access: 26 March 2019), 2016.

van der Laan-Luijkx, I. T., van der Velde, I. R., van der Veen, E., Tsuruta, A., Stanislawska, K., Babenhauserheide, A., Zhang, H. F., Liu, Y., He, W., Chen, H., Masarie, K. A., Krol, M. C., and Peters, W.: The CarbonTracker Data Assimilation Shell (CTDAS) v1.0: implementation and global carbon balance 2001-2015, Geosci. Model Dev., 10, 2785-2800, https://doi.org/10.5194/gmd-10-2785-2017, 2017.

VDI - Fachbereich Umweltmeteorologie: Dispersion of air pollutants in the atmosphere; determination of plume rise, Tech. Rep. VDI 3782 Blatt 3, VDI/DIN-Kommission Reinhaltung der Luft (KRdL) - Normenausschuss, available at: http://www.vdi.eu/nc/guidelines/vdi_3782_blatt_3-ausbreitung _ von_luftverunreinigungen_in_der_atmosphaere_berechnung der_abgasfahnenueberh/ (last access: 26 March 2019), Richtlinie, technische Regel, can be ordered from Beuth Publishing, Germany, 1985.

Vogel, B., Vogel, H., Bäumer, D., Bangert, M., Lundgren, K., Rinke, R., and Stanelle, T.: The comprehensive model system COSMOART - Radiative impact of aerosol on the state of the atmosphere on the regional scale, Atmos. Chem. Phys., 9, 8661-8680, https://doi.org/10.5194/acp-9-8661-2009, 2009.

Zubler, E. M., Folini, D., Lohmann, U., Lüthi, D., Muhlbauer, A., Pousse-Nottelmann, S., Schär, C., and Wild, M.: Implementation and evaluation of aerosol and cloud microphysics in a regional climate model, J. Geophys. Res.-Atmos., 116, D02211, https://doi.org/10.1029/2010JD014572, 2011. 